\title{
THE FRENCH (TRADE) REVOLUTION OF 1860: INTRA-INDUSTRY TRADE AND SMOOTH ADJUSTMENT
}

\author{
Stéphane Becuwe \\ Bertrand Blancheton \\ Christopher M. Meissner \\ Working Paper 25173 \\ http://www.nber.org/papers/w25173 \\ NATIONAL BUREAU OF ECONOMIC RESEARCH \\ 1050 Massachusetts Avenue \\ Cambridge, MA 02138 \\ October 2018, Revised September2019
}

Previously circulated as "International Competition and Adjustment: Evidence from the First Great Liberalization." Helpful comments from seminar participants at UC Davis and Brian Varian are acknowledged. Yang Gao provided helpful research assistance. The views expressed herein are those of the authors and do not necessarily reflect the views of the National Bureau of Economic Research.

NBER working papers are circulated for discussion and comment purposes. They have not been peer-reviewed or been subject to the review by the NBER Board of Directors that accompanies official NBER publications.

(C) 2018 by Stéphane Becuwe, Bertrand Blancheton, and Christopher M. Meissner. All rights reserved. Short sections of text, not to exceed two paragraphs, may be quoted without explicit permission provided that full credit, including $\odot$ notice, is given to the source. 
The French (Trade) Revolution of 1860: Intra-Industry Trade and Smooth Adjustment

Stéphane Becuwe, Bertrand Blancheton, and Christopher M. Meissner

NBER Working Paper No. 25173

October 2018, Revised September2019

JEL No. F13,F14,N7

\section{$\underline{\text { ABSTRACT }}$}

The Cobden-Chevalier treaty of 1860 eliminated many French import prohibitions and lowered tariffs between France and Britain. Policy change was largely unexpected and unusually free from direct lobbying. A series of commercial treaties with other nations followed because of the use of the unconditional-MFN clause. Post-1860 in France, we find a significant rise in intraindustry trade. On average, rising imports did not prejudice exports. Liberalization allowed for an expansion of two-way trade in differentiated products. The findings are consistent with the "smooth adjustment" hypothesis. Anti-competitive, protectionist lobbying apparent from 1878 was not necessarily a backlash to enhanced international competition.

Stéphane Becuwe

GREThA UMR CNRS 5113

University of Bordeaux

Avenue Duguit

33608 Pessac

France

stephane.becuwe@u-bordeaux.fr

Bertrand Blancheton

GREThA UMR CNRS 5113

University of Bordeaux

Avenue Duguit

33608 Pessac

France

bertrand.blancheton@u-bordeaux.fr
Christopher M. Meissner

Department of Economics

University of California, Davis

One Shields Avenue

Davis, CA 95616

and NBER

cmmeissner@ucdavis.edu 


\title{
The French (Trade) Revolution of 1860: Intra- Industry Trade and Smooth Adjustment*
}

\author{
Stéphane Becuwe \\ GREThA - UMR CNRS 5113, University of Bordeaux \\ Bertrand Blancheton \\ GREThA - UMR CNRS 5113, University of Bordeaux \\ Christopher M. Meissner \\ University of California, Davis \& NBER
}

September 6, 2019

\begin{abstract}
The Cobden-Chevalier treaty of 1860 eliminated many French import prohibitions and lowered tariffs between France and Britain. Policy change was largely unexpected and unusually free from direct lobbying. A series of commercial treaties with other nations followed because of the use of the unconditional-MFN clause. Post-1860 in France, we find a significant rise in intraindustry trade. On average, rising imports did not prejudice exports. Liberalization allowed for an expansion of two-way trade in differentiated products. The findings are consistent with the "smooth adjustment" hypothesis. Anti-competitive, protectionist lobbying apparent from 1878 was not necessarily a backlash to enhanced international competition.
\end{abstract}

\section{Introduction}

How do industries react and survive in the wake of extreme trade liberalization? Over the last thirty years, the global economy has rapidly and substantially reduced tariffs

\footnotetext{
${ }^{*}$ Helpful comments from seminar participants at UC Davis and Brian Varian are acknowledged. Yang Gao provided helpful research assistance. Corresponding author: Christopher M. Meissner, University of California, Davis One Shields Avenue Davis, CA 95616 email: cmm@ucdavis.edu; Stéphane Becuwe GREThA - UMR CNRS 5113, University of Bordeaux Avenue Duguit 33608 Pessac, France email: stephane.becuwe@ubordeaux.fr; Bertrand Blancheton, GREThA - UMR CNRS 5113, University of Bordeaux, Avenue Duguit 33 608 Pessac, France bertrand.blancheton@u-bordeaux.fr
} 
and scaled back sundry trade barriers. China's integration into the WTO and establishment of most-favored nation status with the US after 2001 is alleged to have caused great dislocation in advanced countries' labor markets (Autor et. al., 2013; Feenstra and Sasahara, 2017). Besides this massive shock, globalization and integration has greatly intensified since the 1970s. Studies of these trade shocks and adjustments to specialization, labor markets and political economy have proliferated.

What can we learn from history and the first wave of globalization? In 1860, France and Great Britain surreptitiously negotiated the landmark "Cobden-Chevalier" trade treaty dramatically decreasing barriers to trade and tariffs between both countries on a large set of important products. British tariffs on French wine and many other key manufactured goods were reduced to very low levels. Numerous French import prohibitions for key products such as cotton and woolen cloth and many varieties of cotton threads were substituted for tariffs. After signing the treaty in 1860 with Great Britain, France signed over a half dozen other bilateral commercial treaties in the 1860 s, all of them featuring unconditional Most Favored Nation (MFN) clauses. Adolphe Thiers, a member of the French opposition, reportedly argued as early as 1862 that the Cobden Chevalier treaty had "wantonly ruined our manufactures". ${ }^{1}$

Recent research by Markus Lampe (2009) has convincingly demonstrated that these types of trade treaties promoted trade in the targeted products and in proportion to the way in which liberalization unfolded. ${ }^{2}$ International competition undoubtedly stiffened. In terms of adjustment in the local economies, less is known despite many important contributions on the "grain invasions" and the subsequent "tariff backlash" (e.g., Gourevitch, 1977 and O'Rourke, 1997). This literature argues that inexpensive grain imports from New World producers, and lower overall trade costs after the 1850s, raised international competition. In France, and in Germany too, farmers and industrial interests formed politically powerful coalitions demanding higher tariffs from 1879 (Germany) or from 1878 (France). ${ }^{3}$

\footnotetext{
${ }^{1}$ Cited in Coutain (2009) p. 153.

${ }^{2}$ Flandreau and Accominotti (2008), studying aggregate trade in the period, found little effect of trade treaties. Aggregation bias may be responsible for the difference between their findings and Lampe's.

${ }^{3}$ Not all countries raised tariffs after the 1870s. Great Britain, the Netherlands, Denmark, and Belgium remained staunchly in favor of low trade barriers. See Henriksen et. al (2012) on Denmark and Huberman (2008) on Belgium. France resisted higher tariff proposals throughout the 1870s and 1880s waiting instead until 1892 to make drastic changes to the liberal policies of the 1860s (Smith, 1980; Coutain, 2009).
} 
Was the eventual rise in French tariffs from the 1880s a response to the treaties of the 1860s or not? We believe they were not. This is a long delay. Two potential answers for the absence of a more immediate reaction are: the liberalization was not very significant; or the adjustment costs of the shock were politically and economically tolerable. The former could be consistent with Flandreau and Accominotti (2008). The second view has not been well studied. A third view, based on Coutain (2009), argues that the treaty system that emerged in the 1860s was self-reinforcing. The logical implication is that open international markets benefitted France's economy in aggregate more than a return to the pre-1860 status quo ex ante would have.

Moreover, as we discuss below, for France, the liberalization clearly was significant. 1860 was a major watershed in the history of trade policy for many other countries as well. The economies involved were not small; the impact on trade was non-negligible. In the middle of 19th century, France was the world's second largest exporter, Great Britain being the largest and most advanced exporter. If any trade agreement in the entire history of the global economy were to be of consequence, then the Cobden Chevalier treaty of 1860 would be one of them. Moreover, there were large incentives for a host of smaller countries to join the network of commercial treaties due to fears of trade diversion and loss of market share. Consequently, in the 1860s over half a dozen other treaties were signed by France in short succession with the leading nations of Europe. Similar treaties proliferated on the European continent between third countries too (Lampe, 2009).

In light of this, we hypothesize that adjustment costs may not have been that high. The data are consistent with the second view enunciated above. Ostensibly, the benefits of free(er) trade were greater than those under alternative, more autarkic policies. We show that adjustment was likely to be tolerable and consequently beneficial in aggregate. We provide evidence consistent with the idea that France diversified its export base and differentiated its products throughout the 1860s and in especially response to the Cobden Chevalier treaty and intensified international competition. Head-to-head, intra-industry trade was the hallmark of the 1860s and 1870s. This dynamic is potentially key for understanding why the great liberalization of the 1860s was not met with more resistance. Rather than imposing a massive sectoral reallocation of resources and a painful adjustment, French producers seemingly met international competition with a strategy of differentiation and niche competition.

Since the 1990s the hypothesis has been put forward that increases in intra-industry trade involve a very different (and less costly) adjustment process than those associated 
with increased inter-industry trade and shifts in specialization (Greenaway et. al., 1994 and Hamilton and Kneist, 1991). Brülhart and Elliott (2002) discuss the "smooth adjustment hypothesis" which states that liberalization might be less disruptive and adjustment dynamics less costly when trade expansion is intra-industry. Inter-industry trade would imply that large sectoral re-allocations would have to take place implying short-run unemployment of specific factors. Even if French producers were to survive, greater competition in homogeneous goods in direct competition would require costly investments and technological upgrading to stay competitive. Our data are consistent with the idea that France was able to avoid a massive re-allocation of factors of production (i.e., labor or capital) between sectors where rigidities might have made the transition more difficult. Our evidence shows significant support for "smooth adjustment" in France for the 1860s.

As we show, the development of intra-industry trade was rapid after 1860 especially in the leading industries of cotton, wool and silk cloth. France was able to sustain global sales even as imports surged. This result may seem anachronistic since intra-industry trade (IIT) was "discovered" in the 1960s. However, a path-breaking study on Germany due to Brown (1995) highlighted that IIT was important in the realm of textile trade circa 1913. In contrast to Brown (1995) we study a broader range of products as well as focusing on the case of France rather than Germany. It should also be emphasized that the previous literature has already identified IIT in France (Becuwe and Messerlin, 1986). Rather than simply document its existence as in Becuwe and Messerlin (1986), our study emphasizes that IIT was causally driven by the liberalization of French foreign trade in the period. This is potentially helpful in understanding a seeming paradox. Gourevitch (1977, p.294) argued that textiles, as well as highly capitalized sectors in industry, were "vulnerable" after liberalization. He also noted the paradox of the long delay in tariff backlash in France. Rather than ascribing the delay to political economy factors as did Gourevitch, we believe that the impact on these sectors was not immediately as negative as previously thought and that these sectors were more resilient than supposed.

We proceed by analyzing several new datasets of dis-aggregated French exports and imports for the decades surrounding 1860. We begin with an analysis of the 104 broad products listed in French official trade statistics. We decompose changes in imports and exports into intra-industry movements, increased specialization and loss of previous specializations using a technique due to Bastos and Cabral (2007). This decomposition establishes that increased intra-industry trade was paramount in the wake of liberalization. 
We then turn to an analysis of the top nine largest exports in the broad product classification scheme during the period. For each of these broad products we have data on between four and 48 sub-products for a total of up to 189 highly disaggregated "subproducts". These top exports, including textiles (cotton, silk and wool) were allegedly some of the most "vulnerable" due to British competition and interest groups historically had vociferously opposed international liberalization. ${ }^{5}$ At this highly disaggregated level, once again, we see a significant degree of increased intra-industry competition. The elimination of prohibitions and the decline in tariffs due to liberalization led to larger rises in their indexes of intra-industry trade after 1860 .

A third test examines the bilateral exports and imports of these top nine products for the universe of France's trade partners. Intra-industry trade at the bilateral level was higher post-liberalization, after a period of transition, especially in key products that had rabidly resisted liberalization prior to 1860 such as cotton, silk and wool cloth. While representatives of these key industries had argued in the early 1850s that French production would be eliminated by removing prohibitions, their pre-liberalization claims seem to have been greatly exaggerated. A better explanation for their pre-and post-period protestations is simply rent-seeking, in effect an attempt to retain monopoly power via targeted policy and privilege.

Our bottom line is that France experienced gains from international trade via trade in differentiated goods. Rather than massively disrupting the economy and leading to between sector transitional challenges, as is emphasized in specific-factors trade theories with market rigidities, France managed its liberalization at tolerable economic cost. While comprehensive employment and output data for France are not available in this period, our story is consistent with the idea that, at the very least, French producers and workers were able to compete through within-industry product differentiation in order to maintain market

\footnotetext{
${ }^{4}$ Specifically we have: 4 for clothing, 5 for raw wool, 48 for tools, 24 for leather, 16 for raw silk, 24 for cotton cloth and thread, 20 for wool cloth and thread, 44 for silk cloth and thread, and 4 for wine. Most French imports in the late 1840s through the 1850s were raw materials. The top 10 imports using import values averaged over 1856 to 1859 were: raw silk (15\%), wool/cotton fibers (10\%), grains (8\%), raw wool (8\%), raw sugar $(7 \%)$, wood (6\%), coal (5\%), leather and skins (4\%), animals (3\%) and coffee $(3 \%)$. These shares did not change too much by 1869-72. Oil seeds displaced coffee as the $10^{\text {th }}$ most important import by then.

${ }^{5}$ We focus on nine products instead of the top 10 because the $10^{\text {th }}$ is a classification called "Articles of Paris". These included luxury items and handicrafts but which had little international competition by definition. These items were however subject to British tariffs and an object of discussion in the 1859 treaty negotiations between France and Britain.
} 
share. ${ }^{6}$ There is little doubt that the economic environment became more competitive postliberalization, but the competition is more consistent with models of differentiated goods rather than homogenous goods. ${ }^{7}$ We discuss below the process and reaction to liberalization, about which much has been written. But at this point we believe it is no overstatement to say that 1860 was a watershed in the history of modern international trade. Our study reveals that the first wave of globalization involved significant intra-industry trade and not simply increased specialization at the broad sectoral level.

\section{Liberalization in the Second Empire}

\subsection{Theoretical Considerations}

How might a country at the early stages of industrialization adapt to intensified international trade after a sharp break towards a more liberal trade policy regime? The most basic models of international trade posit three potential routes. In a Ricardian model of homogeneous comparative advantage, trade is based on differences in relative productivity. In many leading Ricardian trade models, trade liberalization promotes complete specialization. In the two-country setup of Dornbusch et. al. (1977) each country expands its range of exports after liberalization while a number of goods previously domestically produced are now sourced from abroad. Marginal sectors will be eliminated by international competition. ${ }^{8}$ These marginal sectors which were afforded protection and sustained by trade policy would be expected to be in decline after liberalization. Products already being exported should not see increased import competition, and those being imported prior to liberalization should not see a significant rise in exports.

In a factor-endowments approach, inter-industry trade, between the labor scarce, resource abundant New World and the labor-abundant, land-scarce Old World, is associated with homogeneous products and weak export diversification. According to O'Rourke and Williamson (1999), falling international trade costs promoted long term convergence in real

\footnotetext{
${ }^{6}$ Juhasz (2019) finds that the temporary protection from international competition afforded by the Napoleonic blockades stimulated learning-by-doing for the cotton spinning industry in early $19^{\text {th }}$ century France. Another interpretation of our findings, worth further investigation, is that pre-1860 trade policy allowed French exporters to become more price competitive and resilient after liberalization than they would have been without earlier protection.

${ }^{7}$ We do not make an explicit distinction between horizontal and vertically differentiated products in this paper, but quality upgrading could be part of the story and consistent with our findings.

${ }^{8}$ Similar logic would apply in the more general Ricardian framework of Eaton et. al (2001).
} 
wages consistent with greater sectoral specialization. ${ }^{9}$ Trade liberalization would be associated with an increase in specialization in products in which France had a comparative advantage. Net exports of products with positive net exports under a highly restrictive trade regime would be expected to increase. Net exports would decline in sectors where even under protection net exports were negative. In sectors where import prohibitions were used, net exports could rise or fall. Still, these models would not predict "matched marginal trade". That is, a rise in both exports and imports in the same product category (i.e., matched marginal trade) is very unlikely in such models. Movement of factors of production between sectors would be expected.

"New" international trade theories feature intra-sectoral competition. Incorporating monopolistic competition and a love of variety. The Krugman (1979) model predicts that industrialized countries produce and trade a wide range of relatively similar goods. Liberalization would lead to an increase in so called intra-industry trade. ${ }^{10}$ Exports and imports would rise together. While some incumbent producers are likely to be eliminated by international competition, factors of production move out of losing firms to other firms in similar sectors. Transition costs are expected to be relatively low. This type of adjustment is "smooth" in the sense that temporary wage disparities and unemployment of the expanding and contracting activities are contained within the same industry. In Ricardian or factor-endowment driven models, trade is based on movement between industries and sectoral re-allocation (Greenaway and Milner, 1986). The assumption is that the mobility of labor is easier and smoother within industries that between. ${ }^{11}$ Considering the history of integration in the European Union since the 1960s, Brülhart and Elliot (1998) show that

\footnotetext{
9 The two-sector "specific-factors" approach analyzed by O'Rourke (1997) suggests that it was paradoxical for industry and agrarian interests in Germany to form a protectionist coalition in the 1890s. New trade theory simplifies the analysis without losing predictive power. Protectionism can benefit any sector in the standard monopolistic competition model (without imported intermediates) by raising producer prices and markups and weakening competition. Such coalitions are not unexpected, nor is it necessary to alter the model in an ad hoc way to understand this coalition as would be required in the factor-endowments trade approach.

${ }^{10}$ In Lancaster (1980) intra-industry trade grows in response to diversification on the demand side. Becuwe, Blancheton, and Meissner (2018) discuss the diversification of France's exports in this period.

${ }^{11}$ Unfortunately sectoral employment data disaggregated at the same level of the trade data is not available for the 1850s and 1860s. Data for a handful of aggregated industrial sectors is available in the late 1840s and early 1850 s and also from the census conducted in the early 1860s. Still the low frequency of the data makes it less useful for tests of the re-allocation of labor between the late 1850s and the late 1860s.
} 
IIT played a key role in the "smooth adjustment process" to trade liberalization and a more integrated European economy ${ }^{12}$.

\subsection{Historical Background on the Great Liberalization of the $1860 \mathrm{~s}$}

Throughout the 1840s, France remained deeply attached to protectionism. Todd (2008) analyzes the formation of the protectionist culture which triumphed over French opinion throughout the 1840s and 1850s. The prologue to our study starts in 1848, the end of 'Monarchie de Juillet' and the start of Second Republic (February, 1848). In December 1848, Louis Napoleon Bonaparte was elected President of the Second French Republic.

Prior to this, various pressure groups, with intellectual support from J-B Say, campaigned in the 1830s for the removal and reduction of formal trade barriers. Almost immediately, these free trade ideas faced a powerful nationalist pushback. According to Todd, the period 1834 to 1844 was marked by a nationalist discourse closely related in spirit to the "national system" of political economy promoted by List. For many industrialists and economists, economic nationalism was desirable as a means to subdue the social tensions wrought by industrialization along the lines of the "English model". Demier notes (2009, p. 147) "most of the products that France could do without, in particular, manufactured goods, were prohibited". Demier counts 58 prohibitions for imports and 12 for exports in the 1840s. These prohibitions, most of which originated in the 1790s, would ultimately be thought to be the force sustaining French production of cotton cloth and textiles as well as other manufactured goods. It was widely believed that Great Britain, and soon other upstart industrializers, would eliminate domestic production and the associated jobs if the trade regime were to have become more liberal. Dunham (1930) notes that this view was most strongly held by cotton industrialists, but that several economists actually believed that limited competition prevented modernization of French metallurgical and cotton industries.

Despite some lonely voices, free trade ideas had few fans in France in the two decades prior to 1860 as manufacturers vigorously promoted the idea that international competition would lead to national ruin. In February 1846, the 'association pour la liberté des échanges' was created at a gathering of French economists. Frédéric Bastiat was the leader. The movement in favor of free trade foundered, torn and riven by internal tensions and political

\footnotetext{
${ }^{12}$ At the SITC five-digit level the share of IIT increased to 0.48 in 1961 to 0.64 in 1992 for eleven countries in European Union.
} 
divisions. Arguments remained doctrinaire and un-rooted in any real empirical examination of the issues.

In September 1846, in response to the free-trade movement, industrial leaders created the "association de défense du travail national". The goal of this society was to maintain active commercial policy based on patriotism and the unique economic identity of France. Without protection from international competition, British competition in particular, national industry would suffer. The protectionist campaign was a success, conquering popular opinion by adopting an Anglophobe discourse. The democratic and Socialist left joined the protectionist camp and such sentiment could be declared politically dominant by 1848. Adolphe Thiers' protectionist views prevailed. Political liberalism distanced itself from free trade. The movement to relax trade restrictions did not totally die out, however.

Indeed Louis Napoleon Bonaparte himself harbored aspirations for more liberal policies. Because of his exile in Great Britain, he was familiar with and became himself a proponent of free trade ideas. Deiss (2018) suggests that Napoleon viewed free trade as a means to national economic development and improved welfare. Napoleon III had a grand vision for liberalization and reform of the French economy including adjustment loans to industry post-liberalization, improved infrastructure, further trade treaties and a progressive reduction in first tariffs on inputs and then on final goods.

Nevertheless, throughout the 1850s, his government was not strong enough to promote a comprehensive reform. Some progress was made however by means of executive power. Between 1853 to 1856, in accordance with the Act of December 17, 1814, tariffs on some raw materials (coal, iron, some types of steel, wool, and several other raw materials) were reduced by executive decree. ${ }^{13}$ These reductions in tariffs might be seen as re-orienting France in the direction of liberalization, but they also represented a higher effective rate of protection for manufactured products given that these changes applied to key industrial inputs.

In 1856 the Government attempted to abolish existing prohibitions on manufactured goods and replace them by tariffs. Parliament resoundingly defeated these proposals, and the government committed to leaving prohibitions in place until at least 1861. France appeared overwhelmingly opposed to a unilateral reduction of the long-standing policies to protect its manufacturing sector.

${ }^{13}$ See Lack (1861) p. 14. 
Political allies of Napoleon III (e.g., Chevalier, Persigny and others) concluded however that it might be possible to drive a customs reform through by executive power alone. It was suggested that by using the power conferred by the Senatus-Consulte of December 25, 1852 to the Emperor, the executive could achieve reform via treaty and without parliamentary consent. Throughout the 1850s, Chevalier, amongst other free trade sympathizers, worked political back channels at home and in Britain to lay the ground work for such a treaty. In late 1859 the emperor signaled his approval to commence secret negotiations for such a treaty.

In the fall of 1859, secret negotiations for a new, bilateral treaty of commerce were opened with Great Britain. Policy makers carefully aimed to be free of political lobbying from particular industries and instead aimed for a wholesale liberalization. Negotiations for the French-British treaty were "conducted in the greatest secrecy" (Arnauné, 1911, p.253). Every precaution was taken to prevent political adversaries from discovering the negotiations. In France, apart from the Emperor, only five people were privy to the negotiations (Ministers Rouher, Baroche and Fould, Chevalier and the Ambassador to London Persigny). Under the patronage of Gladstone, Cobden negotiated first alone, then with Lord Cawley. This process culminated with the signing of a treaty of commerce on January 23, 1860, referred to as a "coup d'état douanier" in the historiography (CadierRey, 1988).

The so-called Cobden-Chevalier treaty of 1860 was revolutionary in the realm of manufactured products. Article 1 of the treaty provided a list of 44 broadly defined British products, previously prohibited, which could be imported from late 1861 (5 years after the 1856 compromise) with a tariff not exceeding $30 \%$ in ad valorem terms.

Outright prohibitions on nearly all woolen fabrics, cotton fabrics (with the notable exceptions of "dentelles", nankin cloth, "tulle" with lacework), silk fabrics--only "tulle", cotton and woolen threads, garments and underwear, prepared hides, refined sugar, tools in metal, pottery and glass, garancine, soap, chemical products, medicament, and trinkets still existed through the end of the 1850s. By eliminating these prohibitions, the treaty of 1860 was nothing short of revolutionary. Although tariffs remained in the high-to-moderate level, they would certainly not be prohibitive in most categories. Dunham (1930) noted however that the treaty tariffs for some products in iron and metal remained prohibitive into the 1860 s. 
Lower tariffs on manufactured goods were phased in. Article 16 stated that that French ad valorem tariffs would be progressively lowered after 1860 from $30 \%$ and these were limited to a maximum of $25 \%$ from October 1, 1864. Article 5 declared that British tariffs on 41 products (silk fabrics, perfume, tools in metal, and of course French wines) would be either totally eliminated or reduced drastically. It should be remembered that Great Britain maintained significant levels of protection in the 1850s even after repeal of the Corn Laws. In fact, reducing British tariffs on French-style wines, silk products, and French luxury goods were key components of the negotiation for the Cobden Chevalier treaty. Success for French wine producers was achieved since article 6 introduced special benefits by way of progressively lower tariffs on French wines. ${ }^{14}$ Article 5 abolished British tariffs on silk cloth and over 38 other manufactured and semi-manufactured products including iron and steel, machinery, several types of woolen articles (blankets gloves and non-wool fabrics), and specialized clothing (gloves, stockings etc.). Article 19 introduced the (unconditional) most favored nation (MFN) clause.

The spirit of the new policies echoed Napoleon III's statement during his first meeting with Cobden (in October 1859) "We don't do reforms in France, we make revolutions." ${ }^{15}$ The treaty was to last 10 years until a renewal option could be exercised. The treaty reduced the average rate of all duties in France from $11.8 \%$ in 1859 to $5.3 \%$ in 1861. Figure 2 shows that the average tariff on the 6 manufactured goods within the top 9 exports were significantly higher than those prevailing for two highly exported raw materials (raw wool and silk) the tariffs on which had been reduced to near zero in the mid-1850s (Figure 2). ${ }^{16}$

According to Bairoch (1989), Irwin (1993), O'Rourke and Williamson (1999) and Lampe (2009) the Cobden-Chevalier treaty was decisive at a global level in reducing tariff protection by incentivizing bilateral agreements including the unconditional most favored nation clause. A literature in political science seeks to analyze the determinants and domestic origins of these treaties. Pahre (2008) emphasizes domestic compensation, while Lazer (1999) emphasizes the interaction between domestic economic interests and international relations. Most previous work is of the opinion that the treaty of 1860 and the

\footnotetext{
${ }^{14}$ Cognac exports rose rapidly after 1860 from 150,000 hectoliters in 1860 to 421,000 in 1866. According to Jouannet (1983) in the Cognac region the treaty brought prosperity to the region. Local authorities even named a street after Richard Cobden which still exists in Cognac.

15 "Nous ne faisons pas des réformes en France, nous ne faisons que des révolutions " (Dunham, 1930, p.124).

${ }^{16}$ It should be remembered that actual policy was much more restrictive on most of these goods due to prohibitions.
} 
ensuing development of the Cobden network was a significant break point in international trade relations.

What is less well understood is how the French economy reacted and adjusted in the wake of this period of liberalization. Did French producers in formerly shielded industries suffer an onslaught of imports, a slump in exports, and a loss of production? In other words, did the shock of liberalization require many industries to shed labor and contract? Did the liberalization episode lead to displacement in the labor market and prolonged adjustment as workers and resources were re-assigned to industries in which France had a comparative advantage?

Little work has been done to study the question since detailed disaggregated data on production and labor are not available at a high frequency in this period. One feature of the era is remarkable. Napoleon was not ostensibly politically punished for signing a series of commercial treaties. Nor did the nation's workers rise up in protest. President Thiers attempted, but failed, to raise tariffs in the early 1870s. Thiers, a lifelong advocate of protectionism, failed to calculate the substantial domestic opposition to the move. The international treaty obligations stymied his attempts and implied heavy losses for France in the event of a tariff hike. Little evidence of a decisive backlash is evident in the two and a half decades following 1860s.

\subsection{Liberalization in Mid-19 ${ }^{\text {th }}$ Century France}

A recent literature questions the revolutionary status of 1860. Perhaps it is not really true that Cobden-Chevalier was a turning point. If so, this could explain the lack of an immediate backlash. Some authors emphasize continuity in trade liberalization between the end of the 1840s through the 1860s. Federico (2009) and Sharp (2010) emphasize that liberalization following the abolition of the Corn Laws was not exclusive to Great Britain. Moreover, lower tariff duties in the agricultural sector had of course started before 1846. Measuring trade liberalization with average tariff rates, Accominotti and Flandreau (2008) allege that there was more progress before 1860 than after. Tena, Lampe and TâmegaFernandez (2012) show a significant tariff liberalization in manufactures around the world before Cobden-Chevalier. They observe tariff reductions from the end of 1840s to the end of the 1850 s in poor and rich continental Europe. 
For France this does not seem to be the case where, for instance, effective protection for manufactured cloth likely actually rose in the 1850s due to the earlier fall in the tariff of raw materials. For France, 1860 is clearly the break point when taking into account the abolition of many significant prohibitions and the structure of tariff policy. This point has recently been somewhat obscured by the work of Tena, Lampe and Tâmega-Fernandez (2012) who use data on tariffs faced by British exporters to track the evolution of tariffs between 1846 and 1880. Tena et. al argue that there was a gradual liberalization in process globally prior to 1860 although they do note that "rich Europe" was an exception with tariffs in the 1850s stable but falling dramatically in the 1860s (see their Figure 1, p. 725). Our disaggregated data for France are consistent with this observation.

We use French customs revenue data for three classes of products. The first includes six broad manufactured products from amongst the top 9 exports for France (silk, woolen, and cotton cloth, tools, clothing, leather products). The second consists of cotton, wool and linen threads. The third group is raw silk and raw wool. For each of these categories of broad products we add up total customs revenue and total imports for all sub-products listed in the Tableau dividing the former by the latter. These are average tariff rates for these products. It should be noted that many products were prohibited prior to 1860 and do not enter this particular calculation.

Figure 2 shows there is a small decrease of two percentage points (roughly 13 percent) between 1848-51 and 1856-59 for the six manufactured goods in the list. However, there is a much larger decrease, equivalent to a 45 percent decline, evident between 1856-59 and 1869-1872. Our bottom line is that the liberalization in France after 1860 for the largest manufactured exports was indeed big and economically significant.

Figure 2 also plots the average tariffs for two raw materials (raw silk and wool) and three intermediates (cotton, wool, and linen thread). Lower tariffs rates for raw wools and silks are evident from the mid-1850s. After 1860, statutory tariffs fell for key manufactured goods and manufactured intermediates like thread with the drop in manufactured goods tariffs being phased in by the treaty.

Overall, Figure 2 suggests a somewhat gradualist approach to liberalization whereby liberalization proceeded up the value-added chain. First raw materials tariffs decreased in the 1850s. Key intermediate product tariffs were lowered and prohibitions were eliminated beginning in 1861, according to the rates noted above. Tariff rates on elaborated manufactured goods were lowered, as per the Cobden Chevalier treaty by 1864. In addition, 
in the years after 1860, 11 new treaties with major European nations further lowered overall tariff rates. The treaty system, combined with the unconditional MFN clause, locked nations into a low tariff equilibrium for many years.

\subsection{Identification: The Treaty of 1860 as an Exogenous Shock to Protection}

The treaty of 1860 was immune to directly lobbying and input from economic interest groups. Earlier discussions and debates did take place. There were also unsuccessful attempts to pass legislation, notably in 1856. Still, Napoleon and the free-traders failed to garner consensus throughout the 1840s and 1850s. The Cobden Chevalier negotiations were free from direct lobbying by industrial interest groups since they were conducted in secret with no open debate. Moreover, the precise timing came as a shock given the secrecy surrounding negotiations.

In terms of adjustment, it should also be noted that the government granted and distributed 40 million francs in adjustment loans in the early 1860s. Companies were required to apply for such loans justifying their proposals with plans for technical upgrades to meet increased international competition. These loans were distributed amongst sectors such as metallurgy and cotton as well as others and surely helped ease some of the strains though the amounts given do not appear to be decisive at the aggregate level.

Dunham (1930) details the fortunes of several key industries (iron and steel, cotton spinning and weaving, silk, woolens, wine etc.). While systematic census data is unavailable, he suggests that heightened competition incentivized upgrades to machinery, techniques, processes and products and liberalization generally promoted salutary growth. He also argues, for example, that advanced mechanization in cotton spinning and weaving, one of the industries expected to be hit hardest by liberalization because of British competition, proceeded more quickly after 1860 than prior to 1860 .

In addition particular industries faced various exogenous shocks in the $1860 \mathrm{~s}$ unrelated to trade policy. Notably the cotton industry (in France and abroad) suffered from the cotton-famine induced by the American civil war. Hearings by the French government in 1870 suggested that the cotton industry suffered from the tariff, but Dunham attributes their difficulties to these other shocks. Moreover, there is and was no quantitative evidence 
at the time that British cotton manufacturing had eliminated or reduced French exports and production.

The iron and steel industry benefitted from a demand shock associated with the construction boom in railway building in the 1850 s and 1860 s. In the 1860 s, woolens benefitted from a large increase in the supply of high quality raw wool from Australia and Argentina. It is important to note that these shocks would have affected France's major trading partners to a similar degree and that they were largely determined by forces unrelated to internal economic dynamics in the French economy and could not have been foreseeable in the late 1850s.

\section{Data}

To study the impact of liberalization, we assemble three different datasets for French trade between 1848 and 1877. ${ }^{17}$ Each data set covers a slightly different range of products or has a different level of disaggregation. Our main data source is the Tableau général du commerce de la France avec ses colonies et les puissances étrangères (Tableau général du commerce et de la navigation after 1896). We use "commerce special" (i.e., specific trade)" and not "commerce general" (general trade). Data from specific trade includes the value of goods imported for national consumption and the value of national production exported. Ostensibly "specific trade" excludes goods in transit. Trade is based on calendar years.

Our first data set covers 104 "broad" products for total imports and exports. These are broad classifications equivalent to the 2 or 3 digit level in the SITC classification. For these data, we have total values of exports and imports in current French francs. For about 24 of these products customs revenue is available throughout the period 1856-1872. The limited range of products in the broad dataset with customs revenue is due to the fact that the Tableau regularly reported the top import revenue products using broad classifications. These products comprised between 90 and $95 \%$ of all tariff revenue collects. ${ }^{18}$ With the tariff

\footnotetext{
${ }^{17}$ We provide further details in the data appendix. Data are based on calendar years.

${ }^{18}$ The Tableau reports tariff revenue for all other products but at a much more disaggregated level (SITC 46 digit level) and bilaterally. It was beyond the scope of this project to collect these observations which would number in the thousands and would require aggregation to the broad product level. Again, the data we use covers on average over $95 \%$ of all tariff revenue collected. In 1870 the highest tariff revenue was from coffee covering 38.9 million France or 30\% of all tariff revenue) and the lowest grossing product enumerated was guano covering 0.1 million Francs or $.07 \%$ of all tariff revenue. "Other products" accounted for 8.9 million francs or $7 \%$ of all tariff revenue.
} 
revenue for these products we can calculate the average tariff by product. It is important to remember that another reason for missing tariff data is that many products were prohibited prior to 1860 and that some products were simply not imported and so did not have tariff revenue. ${ }^{19}$ Products are classified (by the authors) into four broad sectors: tropical/exotic, primary, semi-manufactured and manufactured.

Within this dataset we focus on the top nine exports for France as of the 1850s. These broad products include silk, woolen and cotton cloth, wine, leather products, clothing, tools, raw silk and raw wool. The share of these top nine exports on French total exports is very significant: $53.1 \%$ in $1848,56.1 \%$ in 1860 , and $50.4 \%$ in 1870 . This "top nine" data set will provide a foundation for studying the impact on the most significant industries/products from an export-driven view of the economy. Competition with Great Britain was expected to have been very intense in some of these industries, especially cotton cloth and clothing. For each of these nine products, we have the total value of exports, imports and tariff revenue collected in current French francs. With the tariff revenue for these nine products we can calculate the average tariff within the product class and for all of these products together.

A second data set covers bilateral exports and imports of these "top nine" products for over 151 different countries and territories. Quantities, values and unit values are available. With these data we are able to follow the evolution of bilateral trade at the product level prior to and after the signing of various bilateral trade agreements.

A third dataset disaggregates further within the top nine specializations. For the period 1848-1877, we digitized trade data for all sub-products within the top nine specializations. This is the highest level of disaggregation possible in French trade statistics. For this period, the dis-aggregated nomenclature is relatively homogeneous and stable. We have the following sub-product counts within the broad product classes: 4 for clothing, 5 for raw wool, 48 for tools, 24 for leather, 16 for raw silk, 24 for cotton cloth, 20 for wool cloth, 44 for silk cloth, and 4 for wine. ${ }^{20}$

\footnotetext{
${ }^{19}$ We thank an anonymous referee for pointing out that Lack (1860) provides the statutory tariffs pre- and post-Cobden Chevalier. These were defined as specific tariffs for most products. Since these are given as specific tariffs, we do not have unit values for most products, and the aggregation is not totally consistent with official French trade statistics, these are not useful for our quantitative exercise.

${ }^{20}$ In the original data there are several more categories for certain products. The French data distinguish between Bordeaux wine in barrels and wine in barrels for instance. Since imports of the former are impossible by definition we aggregate the former with the latter. Another issues arises for raw wool. Only certain types
} 
For each of these sub-products we have export and import values, quantities and by extension, unit values. For many of these sub-products, data is also available on total customs duties collected. This makes it possible to calculate the ad valorem equivalent of the tariff rates by sub-product or at higher levels of aggregation (as in Figure 2). Finally, we classify sub-products as prohibited based on having zero imports in all years prior to 1860 and with the help of Lack (1861).

\section{Trade policy and Intra-Industry Trade}

\subsection{Measuring the Level of Intra-Industry Trade}

Figure 1 shows that France became increasingly open to trade in the mid-19 ${ }^{\text {th }}$ century in the wake of the generalized decline in trade costs associated with the first wave of globalization (Jacks, Meissner and Novy, 2010). In addition the trade balance declined somewhat especially from the late 1870s. This decline in the trade balance was noted by contemporaries and as has been suggested elsewhere (Levy-Leboyer and Bourguignon, 1985 and 1990). ${ }^{21}$

In order to shed light on the transformation of international competition we study the evolution and determinants of intra-industry trade (IIT) measures in our different data sets. First we compute the Aquino and "corrected" Grubel and Lloyd indexes for the 104 broad products. The Aquino index (AI) is defined as:

$$
\text { Aquino Index }=1-\frac{1}{2} \sum_{i}^{N}\left|\frac{X_{i}}{\sum_{1}^{N} X_{i}}-\frac{M_{i}}{\sum_{1}^{N} M_{i}}\right|
$$

where $X_{i}$ and $M_{i}$ are exports and imports of (broad) product $i(i=1, \ldots, 104)$ and $N$ is the number of products.

The corrected Grubel and Lloyd is defined as:

\footnotetext{
of sub-products are broken down for imports but not exports in certain years. We also aggregate these together for consistency.

${ }^{21}$ Levy-Leboyer (1985) also notes declines in net exports of $40 \%$ to $60 \%$ on certain products. "A partir de 1876-1879, des baisses souvent très brutales, de l'ordre de 40 à $60 \%$, parfois davantage, se sont produites en effet sur la vente de produits..."
} 


$$
\text { Corrected Grubel Lloyd Index }=\frac{\sum_{i}^{N}\left(X_{i}-M_{i}\right)-\sum_{i}^{N}\left|X_{i}-M_{i}\right|}{\sum_{i}^{N}\left(X_{i}-M_{i}\right)-\left|\sum_{i}^{N} X_{i}-\sum_{i}^{N} M_{i}\right|}
$$

The Grubel Lloyd Index is defined as

$$
\text { Grubel Lloyd Index }=1-\frac{\sum_{i}^{N}\left|X_{i}-M_{i}\right|}{\sum_{i}^{N}\left(X_{i}+M_{i}\right)}
$$

Figure 3 shows the evolution of these indicators of IIT. The Aquino and GrubelLloyd indexes are highly correlated. Intra-industry trade as a share of total trade rises from 12-14 percent in 1859-60 to 38 percent in 1872. A notable acceleration is evident in the 1860s coincident with liberalization. From Figure 3 we can see that even if intra-industry trade was "discovered" by Verdoorn in 1960, it constitutes one of the main contributing factors of the French foreign trade since the 1850s. Our data establishes a rapid development of IIT from about 1860 through the 1870s.

\subsection{Measuring "Marginal" Intra-Industry Trade and Specialization Shifts}

In looking at the dynamics of trade, the Grubel-Lloyd index has some drawbacks as discussed in Greenaway et. al. (1994). The GL index can of course rise when net exports fall for example when exports are constant and there is a rise in imports. Figure 4 plots net exports for selected products. Most products see a slowdown in the growth of net exports after Cobden-Chevalier and a lower level almost immediately after the treaty was signed.

As in the previous section, it is of importance to study the overall share of trade that is "matched" in equilibrium with the Grubel Lloyd measure. In thinking about adjustment to the new equilibrium and changes in specialization it is also useful to investigate dynamics and the changes in trade.

The methodology developed by Bastos and Cabral (2007) allows us to decompose changes in trade into the fraction of the change in trade accounted for by intra-industry trade. Such a "marginal" decomposition allows us to have an index of how much the changes in trade were accounted for by modern, intra-industry trade as opposed to growth in 
products where there is specialization (as measured by net exports). We emphasize that these measures provide information on the margin and not about the levels.

Bastos and Cabral (2007) "decompose the trade change into three different components: 'marginal intra-industry trade' (MIIT), inter-industry trade growth that contributes to an increase in a country's previous specialization (IPS), and inter-industry trade growth that contributes to a decrease in a country's previous specialization $(S S)$ ". For the first, define MIIT from Brülhart (1994) as

$$
\operatorname{MIIT}_{i t}=1-\text { INTER }_{i t}=1-\frac{\left|\Delta X_{i t}-\Delta M_{i t}\right|}{\left|\Delta X_{i t}\right|+\left|\Delta M_{i t}\right|}
$$

Bastos and Cabral (2007) note that the portion of trade not allocated to marginal intraindustry trade can be classified in one of two ways as follows:

$$
\begin{aligned}
& \boldsymbol{I P S}_{\boldsymbol{i t}} \text { if sign } \Delta X_{i t}-\Delta M_{i t}=\operatorname{sign}\left(X_{i 0}-M_{i 0}\right) \\
& I_{N T E R_{i t}}=\boldsymbol{S S _ { i t }} \text { if sign } \Delta X_{i t}-\Delta M_{i t} \neq \operatorname{sign}\left(X_{i 0}-M_{i 0}\right)
\end{aligned}
$$

In these expressions, $\Delta X_{i t}$ and $\Delta M_{i t}$ are respectively the change in exports and imports between period $t$ and a base period for product $i$. MIIT measures the share of the growth in exports that is matched by a rise in imports. Like the Grubel-Lloyd index, MIIT varies from 0 to 1 . If MIIT equals 1, trade expansion is entirely "matched" and is wholly intra-industry. If $M I I T=0$, the entirety of the growth in trade is of the inter-industry type. The MIIT index can be calculated at the aggregate level as well as by trade partner and by product. The base year for differences is also obviously flexible. It is useful to keep in mind that $M I I T$ is strictly increasing in net exports whilst the GL index can increase when net exports decrease.

For inter-industry trade $X_{i 0}$ and $M_{i 0}$ are respectively the exports and imports in a product in an initial period. We assign a positive sign to net exports when initial net exports, $X_{i 0}-M_{i 0}=0$. IPS represents movements in trade that contribute to an increase in a previous specialization. A product in which France was a net exporter in the initial period and for which exports grew faster than imports would assign INTER to IPS. Similarly, if in 
a product France was initially a net importer and imports rose faster than exports then we assign INTER as IPS.

$S S$ represents inter-industrial movements that involve shifts in specialization. Movements here contribute to a weakening of a previous specialization through lower net exports in industries where net exports were positive or through lower net imports when net exports were previously negative. To understand changes in $S S$, consider a particular product where imports are limited by the trade policy regime of the 1850s. Net exports are initially higher (or no lower) than under the low tariff policy of the 1860s (ceteris paribus) due to the negative impact of tariffs or prohibitions on imports. Liberalization, causing a rise in imports, not matched by exports, and hence a decrease in the net exports of such a product, would be associated with higher values of $S S$.

Coming back to the example of a rising $G L$ index with falling net exports allows us to see the difference between the marginal measures (MIIT, SS and IPS) and the levels measure $(G L)$. If net exports were positive prior to liberalization and only imports rise postliberalization, then $G L$ would rise, $M I I T$ is zero, IPS is not defined and $S S$ is positive. The difference $I P S-S S$, also of interest in the empirics below, would be negative. In other words, on the margin, France shifted specialization. However, one might be interested in the overall level of intra-industry trade in the long-run. For this, the $G L$ measure in levels dominates. We study both types of variables below.

The data used to calculate the marginal decompositions cover up to 104 broad products. We calculate the weighted average from each product's decomposition using initial trade values as weights. We also smooth the trade data over four year periods to minimize the impact of short-run shocks. Our initial reference period is $1848-1851$. We also provide a calculation using 1856-59 as the pre-liberalization baseline period. We track the evolution of MIIT, $S S$ and IPS for up to 1869-72.

The evolution of MIIT, IPS, and $S S$ are presented in Table 1 for all 104 broad products and for the top nine specializations of France. Again, these figures represent weighted averages of the individual product indexes. Table 1 shows a sharp increase in the share of trade growth accounted for by intra-industry trade in the wake of the trade liberalization of 1860. At the same time, increased international competition is associated with a deceleration in the overall degree of specialization as seen by the declining share of trade growth accounted for by $I P S$. The share and trends in $S S$ are less pronounced. For all products, prior to liberalization, SS, accounted for $15 \%$ (1852-55) or 8\% (1856-59) of 
trade growth. In the 1870s these values vary between $10 \%$ and $12 \%$. Because the differences are with respect to a common base period, this implies very little of the growth in trade came from products that were "artificially" promoted prior to liberalization.

On the face of it, these trends are not in strong agreement with the predictions of either the Heckscher-Ohlin factor endowments trade model or the Ricardian model. Recall that both models would predict strong movement in the direction of revealed comparative advantage and net exports. IPS, the component of the growth in trade that would be most supportive of these trade models, never explains more than $50 \%$ of the growth in trade when 1856-59 is used as a baseline. Its share also decreased over time as trade barriers fell further.

Although the rise of intra-industry trade seems to come after the shock of 1860, this phenomenon persists and even increases somewhat over time. This is likely due to the fact that liberalization continued as a number of new trade treaties were signed with European partners and the technologies propelling the first globalization diffused.

\subsection{Marginal Intra-Industry Trade and Specific Industries}

Figure 3 and Table 1 show evidence that IIT accelerated in the wake of liberalization. Here we attempt to see which types of products were most affected by the liberalization of the early 1860s. French protectionists siding with various key industrial interests promoted the idea that their interests would be harmed by allowing British products to penetrate the French market. If so, then in the wake of the Cobden Chevalier treaty, manufactured goods and leading industries (especially cotton and woolen cloth, clothing and metal tools) should have seen net exports decline implying a smaller share for IPS or a rise in the share of $S S$. If, on the other hand, lower trade barriers promoted growth in two-way trade in differentiated goods in the most contested industries, then MIIT should have been relatively large post-liberalization.

In addition to studying the evolution of MIIT, IPS and $S S$ we also evaluate the impact of liberalization by assigning each product in the broad product dataset a quantitative treatment level. We then relate changes in tariffs and prohibitions to changes in the level of intra-industry trade $G L$ in the spirit of a difference-in-differences test. At the broad product level (104 products) we have tariffs for 24 products prior to and postliberalization. However, many products were prohibited prior to 1860 with a range of tariffs applied post-1860. We cannot reasonably assign a pre-treaty tariff rate to prohibited 
products. However, we can use a prohibition indicator as a measure of the change in liberalization. We compare the "treated" pre-1860 prohibited goods to all other goods that were not prohibited, and then in robustness checks compare only to goods for which average tariffs stayed relatively constant.

In Table 2 we summarize the evolution of $M I I T$ and IPS-SS for manufactured goods and the top nine products relative to a control group. The control groups are either unmanufactured products or all products outside of the top 9. Trade data is for the 104 products in the French trade data. The goal here is to see whether these important and strategic classes of products reacted differentially in terms of changes in the composition of trade post-liberalization.

Our first dependent variable is $M I I T$. The second dependent variable is the difference between IPS and SS (IPS-SS) following Bastos and Cabral (2007). IPS-SS is larger when specialization in revealed comparative advantage goods increases. It is smaller when shifts in specialization occur. Since $M I I T, I P S$ and $S S$ are defined as differences between a base period and a later period we do not include product or category fixed effects. The constant and period dummies allow for common shocks in the post-liberalization period. With this specification we can interpret the coefficients as a difference-in-differences with the preliberalization period of interest 1856-59 and the post-liberalization periods of 1861-64, 186568 and 1869-72. Specifications take the following form:

$$
M I I T_{i}=\kappa+\beta\left(\operatorname{manufactured}_{i} \mathrm{x} \delta_{t}\right)+\delta_{t}+\varepsilon_{i}
$$

with $i$ indexing a product in the set of 104 products in our dataset and $t$ indexing the three post-liberalization periods. Period dummies are collected in $\delta_{t}$.

Results for these regressions are presented in Table 2. For manufactured goods in general, the MIIT share was slightly higher in the years following Cobden Chevalier. The column labelled IPS-SS shows that specialization in manufactured goods tended to increase in the years following Cobden Chevalier.

For the top nine specializations, column 3 shows that MIIT was a statistically and economically significant 23 percentage points larger for these products compared to all other products in the immediate wake of the Cobden Chevalier treaty. Column 4 shows that there is no evidence of an increase in previous specializations or a shift in specialization for the 
top nine products. Our conclusion is that while import competition intensified, on average it did not do so at the cost of exports. For the top nine export products, both imports and exports tended to increase together.

\subsection{Intra-Industry Trade and Liberalization}

A word of caution is in order when thinking about changes in the level of the Grubel Lloyd index as compared to MIIT. MIIT, IPS, and SS are conceptually distinct from the $G L$ index as discussed above. The former are about trade on the margin whereas the $G L$ index is a variable in levels, and it also scales by the level of trade. In fact the correlation between MIIT and changes in the GL index is only about 0.24 in the entire sample and 0.14 in the 1861-64 period.

In Table 3 we explore the evolution of the level of $G L$ and a measure of the level of intra-industry trade due to Greenaway et al. (1994) This latter variable is calculated as

$$
I I T_{i}=\left[\left(X_{i t}+M_{i t}\right)-\left|X_{i t}-M_{i t}\right|\right]
$$

and measures the value of gross trade not accounted for by inter-industry trade. This measure gives more importance to industries or products that have a larger share in trade and thus can give insight into the magnitude of the adjustment process. The correlation between changes in the $G L$ index and $\triangle I I T$ is also low at 0.15 .

Table 3 relates the $G L$ ratio, IIT and a logarithmic version of $I I T$ to tariffs. ${ }^{22}$ The data cover 68 of the 104 broad products with data throughout the period. Due to products that have zero trade in both periods we do not have all 104 products for this exercise. We run regressions of the following form including product fixed effects and period fixed effects:

$$
G L_{i t}=\kappa+\beta\left(\operatorname{tariff}_{i}\right)+\delta_{t}+\mu_{i}+\varepsilon_{i}
$$

and

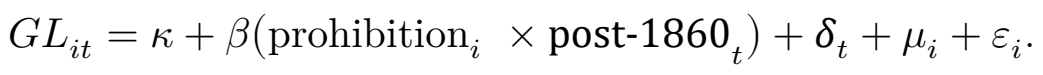

\footnotetext{
${ }^{22}$ Specifically we use $\ln \left[\frac{\left(X_{i t}+M_{i t}\right)}{\mid X_{i t}-M_{i t}}\right]$.
} 
For the first regression we use the average tariff $\left(\operatorname{tariff}_{i}\right)$ for 24 goods. In the second set of regressions, we interact a dummy variable equal to 1 if a product had an import prohibition prior to 1860 with the post-liberalization indicator equal to one in the periods 1861-64, 1865-68 or 1869-72. Because of the use of product fixed effects, $\mu_{i}$, and the timing of the liberalization, coefficients in our setup measure the relative changes in intra-industry trade $(I I T)$ or the Grubel Lloyd share post-liberalization relative to the comparison group as in a typical difference-in-differences setup.

We find that larger declines in tariffs were associated with higher values of $G L$ indexes in the post-1860 years. A one standard deviation decline in the ad-valorem average tariff (-16 percentage points) was associated with a one quarter of a standard deviation rise in the $G L$ index equivalent to a rise of 8 percentage points In addition, products that were prohibited prior to 1860 had an increase in their $G L$ indexes 18 percentage points higher than non-prohibited products post-liberalization. We also restricted the comparison group to products that were admitted prior to 1860 and which had tariff declines no smaller than 0.025 percentage points post-1860 compared to 1856-59. In this case the sample size drops to 88 observations (11 prohibited and 11 admitted products). The coefficient on the interaction term of prohibition and post-liberalization is equal to 020 ( $\mathrm{p}$-value $=0.021$ ).

We also explored a dynamic version of the regressions in column 1 allowing for separate intercepts in all six three-year periods $(1848-51, \ldots, 1869-72)$ and interacting the period dummies with a manufactured indicator or a top ten indicator. For manufactures, no statistically significant association with the $G L$ ratio is evident. For the top nine specializations, all coefficients in the periods after 1860 are positive and significant rising from 0.08 (s.e., 0.04) in 1861-64 to 0.19 (s.e., 0.07, p-value 0.01) in 1869-72. ${ }^{23}$ For these top nine products $G L$ rose significantly after liberalization.

\section{Highly Disaggregated Data: Evidence from Sub-Products within the Top 9}

\subsection{Marginal Intra-Industry Trade}

\footnotetext{
${ }^{23}$ Additionally we classified products into centiles in terms of share of exports in 1856-59 (below the median, the median to the $75^{\text {th }}$ percentile, $75^{\text {th }}$ percentile to the $90^{\text {th }}$ percentile, and above the $90^{\text {th }}$ percentile). We interacted these with each of the six period dummies. Nearly all categories see higher GL ratios post-1860 compared to the baseline period of 1856-59 and no significantly different GL ratio levels compared to the baseline period prior to the $1860 \mathrm{~s}$.
} 
In a similar spirit to Table 2, Table 4 uses value data for sub-products for which we have data in the top nine broad product categories. In principle we have up to 216 separate products here, but since MIIT, IPS and SS are not defined when both imports and exports are zero in both periods we have only 156 sub-products for the years 1861-1864. We use the same dependent variables (MIIT and IPS - SS) as in Table 2 and the base period is also 1856-59. This time we calculate these indicators at the sub-product level. We show results for manufactured goods as a whole as well as coefficients for each broad product class. Each category is interacted with an indicator for the years 1861-1864. Regressions take the following form where an observation $s$ indexes the 156 sub-products:

$$
M I I T_{s}=\kappa+\beta\left(\operatorname{manufactured}_{s}\right)+\varepsilon_{i}
$$

The manufactured goods comprise all the sub-products in the broad categories of wool cloth, silk cloth, cotton cloth, clothing, leather, and tools. The comparison group, nonmanufactured goods, include raw wool and raw silk. Because of the special nature of wine, and its heavy reliance on climate, geography, soil quality, and the agricultural commodity of wine grapes, we leave wine out of the manufactured category for now. We omit the constant in columns 2, 3, 6 and 7 so that coefficients simply represent the average of the dependent variable by category in the 1861-1864 period. Columns 3 and 7 weight with the value of total trade of the product in the baseline period. A positive coefficient implies that within a product class the dependent variable was significantly different from zero in the post-liberalization period.

Column 1 shows that within the top nine products, manufactured goods had a relatively smaller MIIT in 1861-1864 than other products. In fact, the data reveal that the increase in trade within the top 9 exports was more likely to be IIT for raw wool and silk (as columns 2 and 3 show) than for manufactured products. Columns 2 and 3 show that in both weighted and un-weighted regressions, tools, silk cloth, and raw wool and silk had MIIT indicators positive and statistically different from zero. ${ }^{24}$ Using un-weighted regressions (column 2) reveals that post-liberalization MIIT for nearly all broad product categories was statistically significantly different from zero and positive which is consistent

\footnotetext{
${ }^{24}$ We weight observations by average of total trade in both periods for each specific sub-product. We use both periods due to the fact that there are zero values for some products for imports and exports in the initial period.
} 
with results in Table 2. Column 4 shows that a larger decline in tariffs was associated with a smaller MIIT.

Results in columns 5, 6, and 7 show that manufactured products experienced a loss or a shift in specialization on the margin. This was likely due to a larger increase in imports than in exports especially in products where net exports were positive pre-1860. Net exports would have been positive or zero in prohibited categories. In the specific product categories, tools, cotton cloth, and silk cloth have statistically and economic significant declines in specialization. For these latter categories then, those which were well represented in the anti-liberalization camp in the 1850s, the evidence on liberalization is mixed. Cotton cloth and silk cloth for example were highly protected by prohibitions prior to Cobden Chevalier and it is interesting that many of the products within these classifications faced extreme rises in imports so that apparent specialization decreased on the margin. Column 8 shows that products with larger declines in tariffs saw greater shifts in specialization.

Nevertheless, imports do not seem to have eliminated exports. Intra-industry trade in levels was higher after liberalization than before. We illustrate this by studying the dynamics of the $G L$ indicator for each sub-product, $s$, as the dependent variable.

We interact each of the top nine broad product classes with period indicators (1848$51, \ldots, 1873-76)$ and include broad product fixed effects and period fixed effects. We omit the period immediately prior to Cobden Chevalier (1856-1859) as the reference period. Coefficients now show the difference in the dependent variable for a product class from the top nine, $i$, in a given period, $t$, relative to its within product-class value in 1856-1859. Regressions take the following form:

$$
\mathrm{GL}_{s t}=\sum_{i} \sum_{t} \beta_{i t}\left(\text { Product }_{i} \times \delta_{t}\right)+\mu_{i}+\varepsilon_{s}
$$

Figure 5 shows the point estimates for each broad product class and each period. For four out of nine categories, the level of intra-industry trade was higher after 1860 relative to the pre-liberalization period with no significant trends prior to liberalization. These include leather, wool cloth, silk cloth, and cotton cloth. The dynamics reveal that the process of liberalization that progressed between 1860 and the early 1870s led to significant rises in the share of trade accounted for by intra-industry trade especially in the politically sensitive categories of all types of cloth. 


\subsection{Intra-Industry Trade and Liberalization}

In Table 5 we test for changes in the $G L$ index at the sub-product level with the treatment indicators used above: average tariffs rates and prohibitions. For each subproduct we have the total tariff revenue collected for the sub-product which we divide by the value of sub-product imports to measure an ad-valorem tariff rate. This rate must, as is well known, be taken with a grain of salt since it will fluctuate depending on unit prices and the elasticity of demand. Our second indicator is whether a sub-product was prohibited prior to 1860s. We infer prohibition from using the tables in Lack (1861) and checking that imports were zero in all pre-periods but non-zero post-liberalization. Data are for 1856-59 and then the four post-1860 periods as above.

The dependent variable in Table 5 is either the $G L$ index, the Greenaway et. al. measure of IIT or the $\ln (I I T)$ measure. We control for sub-product fixed effects, period effects and cluster the standard errors at the sub-product level. Table 5 shows that larger declines in the "tariff rate" are associated with larger $G L$ indexes and the logarithm of the IIT measure in the post period. Products that are no longer prohibited see relatively higher $G L$ indexes post-liberalization and the log or the IIT measure is also relatively higher postliberalization.

Table 6 attempts to dis-entangle these results by investigating changes in the log of exports, the log of imports or the log ratio of exports to imports. When trade values are zero we add 0.000001 to the value. The left hand side of Table 6 uses the sample of 104 broad products. The right hand side uses the sub-products from the top 9 exports. In both samples, we find that imports grew more strongly the larger the fall in tariffs or for the products where prohibitions were eliminated. Exports of previously prohibited products did not grow differentially compared to non-prohibited products. Column 7 shows that for the sub-product sample exports did grow more quickly the larger the tariff cut, but that they grew more slowly than imports. The level of net exports was apparently not affected by the magnitude of the change in the tariff.

Overall, liberalization promoted a decline in net exports but a rise in the overall levels of intra-industry trade. These results are consistent with the previous findings. Products that saw larger declines in protection had no higher (or lower) growth in exports but imports did increase relatively quickly. The $G L$ index increased implying a move to a new equilibrium with higher intra-industry trade. 


\section{Evidence from bilateral trade}

In the years following 1860, France signed a number of other treaties of commerce with other leading European nations. The incentive to sign such treaties for third countries was large because in the absence of a treaty with an MFN clause demand could potentially be diverted from these countries without treaties towards Great Britain causing a loss of market share for countries without a treaty.

Treaties of commerce including the MFN clause and/or "tailor made' reductions (in the terminology of Lampe, 2009) were signed between France and Belgium (1862), the Zollverein and the Hanseatic League (1863), Italy (1864), Switzerland (1865), the Netherlands, Spain, Sweden and Norway (1866), and Portugal (1867). The difference in timing allows us to explore the impact of trade treaties on intra-industry trade in a large sample of bilateral French trade data with a set of control group countries and territories which did not sign treaties of commerce with France. Specifically we explore regressions of the following form

$$
G L_{c i t}=\omega_{c}+\mu_{i}+\delta_{t}+\sum_{\tau=0}^{m} \beta_{-\tau} \text { Treaty }_{c, t-\tau}+\sum_{\tau=1}^{q} \beta_{+\tau} \text { Treaty }_{c, t+\tau}+\varepsilon_{c i t}
$$

where the dependent variable $G L$ is the level of the Grubel-Lloyd index for product $i$ in trade with country $c$, in year $t, \omega_{c}$ is a set of country fixed effects, $\mu_{i}$ is a set of product fixed effects, and $\delta_{t}$ is a set of year fixed effects. Product fixed effects control for (timeinvariant) product-specific demand and supply features. Country dummies control for timeinvariant determinants of supply and demand for all products. Time dummies control for both global shocks covering all trade partners as well as French year-specific demand and supply shocks affecting all products. We also allow for greater flexibility by allowing for linear country and product time trends which might control for income convergence between France and trade partners are well as other partner-specific trends. The variable Treaty equals 1 if France ever had a treaty of commerce in effect with country $i$. We allow for $q=$ 3 leads captured by $\left(\beta_{+1}, \beta_{+2}, \beta_{+3}\right)$ and the year of signing and 5 lags $\left(\beta_{-0}, \beta_{-1}, \ldots, \beta_{-5}\right)$. We also allow for the impact of treaties six years and beyond. The sample covers the years 1850 to 1870, 74 trade partners with balanced data, and the top nine exported products.

Results in Table 7 support the idea that French trade treaties were associated with a higher Grubel Lloyd index at the bilateral level. On average, the $G L$ index was roughly two log points higher for trade partners with a treaty after controlling for country and product specific linear trends. The point estimate is somewhat higher when country and 
product trends are excluded ( 7 log points). In column (4) we interact the treaty dummy with the partner country indicators to show the evolution of intra-industry trade at the bilateral level. For the major industrialized and industrializing trading partners, coefficients are positive and statistically significant The magnitude of these coefficients are 0.13 for Belgium, 0.18 for the Zollverein, 0.06 for Great Britain, and 0.13 for the Netherlands. Coefficients for Italy, Sweden, Spain, Portugal and Switzerland are not statistically different from 0. Apparently MFN treaties were more likely to promote higher intra-industry trade amongst the more advanced countries.

Information on leads and lags is presented in columns 5 and 6. Leads (columns 5 and 6) are insignificant. There are no significant pre-trends by this measure in column (5). Lags show that the impact of a treaty takes some time to appear. The share of trade accounted for by IIT rises by about three percentage points in the three years immediately following a treaty. Beyond the six year horizon, the $G L$ index is estimated to be a statistically and economically significant 12 to 13 percentage points higher. The results are not robust to inclusion of country and product level trends.

Results for the dynamics for each of the nine products are show in in Figure 6. Most products show no specific pre-event trends but some such as wool cloth, cotton cloth and leather goods are higher after liberalization.

We also explored similar specifications using Greenaway et. al.'s (1994) measure of IIT as the dependent variable and the logarithmic version of that measure. Results are exactly in line and largely qualitatively similar in levels with those above using aggregate data and whether or not we use the logarithmic version of IIT or not. Our results using bilateral trade are largely in line with Brown (1995) who found that in 1913 lower tariffs were associated with higher intra-industry textile trade. We confirm these patterns in a dynamic setting covering a wider range of products.

\section{Conclusion}

The Treaty of commerce signed on January 23, 1860 was one of the most significant events for international trade up to that point in time. The treaty led to a number of followon treaties which locked major European nations into a self-enforcing low-tariff equilibrium (Coutain, 2009). Fortunately, the liberalization can be considered largely exogenous to the demands of specific industries. Being unexpected and motivated by broader ideas and 
concerns about economic development allows us to use the 1860s as a natural experiment to directly study the impact of liberalization on intra-industry trade. This also allows an indirect study of the process of adjustment in France amongst a set of leading industries.

In line with new international trade theories, we show evidence consistent with the idea that that France had a relatively smooth adjustment. This occurred as France differentiated its products and competed intra-industry. Rather than imposing massive inter-sectoral changes in French specialization, the nation was often able to continue exporting its own unique brand in each specific product line. Intra-industry trade is often considered to be a $20^{\text {th }}$ century feature of the data, but it appears to constitute the basis of a large share of trade in late $19^{\text {th }}$ century France.

We also contribute to a recent debate in economic history about the size of the shock in trade liberalization in the 1860s. This issue, driven by research by Accominotti \& Flandreau (2008), Sharp (2010) and Tena et. al. (2012) shows that the status of prohibitions appears crucial. The vast majority of woolen and cotton fabrics were prohibited in France prior to 1860 (with only a few exceptions in sub-products for cotton and woolen fabrics). The shock of Cobden Chevalier was quite large for these product classes. Notwithstanding the fact that this was a massive re-orientation in trade policy, French industry and trade seems to have remained buoyant rising to the demands of international competition. French consumers are also likely to have gained through a higher variety of products available and at lower cost. On the supply side, we emphasize the importance, implicitly, of product quality and differentiation even at early stages of development and in $19^{\text {th }}$ century history which is often under-emphasized in quantitative literature. We have left the study of vertical/quality differentiation and liberalization in the $19^{\text {th }}$ century to further research, but we believe that this could be promising area for helping us to achieve greater understanding of the nature of international competition in the first wave of globalization.

\section{References}

Accominotti, O. and Flandreau, M., 2008. "Bilateral treaties and the most-favored-nation clause: the myth of trade liberalization in the nineteenth century." World Politics, 60(2), pp.147-188. 
Arnaune A., 1911, Le commerce extérieur et les tarifs de douane. Paris, Alcan.

Autor, D. H., D. Dorn, and G. H. Hanson. 2013. "The China syndrome: Local labor market effects of import competition in the United States."' American Economic Review, 103(6), pp. 2121-68.

Bairoch P., 1989. "European trade policy, 1815-1914," in P. Mathias \& S. Pollard (eds.), The Cambridge Economic History of Europe, vol. VIII: The Industrial Economies: The Development of Economic and Social Policies. Cambridge: Cambridge University Press, pp. $1-160$.

Becuwe, S., Blancheton, B. and Meissner, C.M., (2018) "Stages of diversification: France, 1836-1938." European Review of Economic History, 22 (4), pp. 430-461.

Becuwe, S. and Messerlin, P. "Intra-Industry Trade in the Long Run: The French Case, 1850-1913," in D. Greenaway and P.K.M. Tharakan, (eds.), Imperfect Competition and International Trade. Humanities Press: Atlantic Highlands, NJ, pp. 191-215.

Betran C., Huberman M., 2016. "International Competition in the first wave of globalization: new evidence on the margins of trade." Economic History Review, 69(1), pp. 258-287.

Bastos P. and Cabral M., 2007. "The Dynamics of International Trade Patterns." Review of World Economics, 143, pp. 391-415.

Brülhart M. and Elliott R. 1998. "Adjustment to the European single market: inferences from intra-industry trade patterns" Journal of Economic Studies, 25 (3), pp. 225-247.

Brülhart M. and Elliott R., 2002. "Labour-market effects of intra-industry trade: evidence for the United Kingdom." Weltwirtschaftliches Archiv, 138 (2), pp. 207-228.

Brown, J.C., 1995. "Imperfect competition and Anglo-German trade rivalry: markets for cotton textiles before 1914." The Journal of Economic History, 55(3), pp. 494-527.

Cadier-Rey, G., 1988. "Les conséquences du traité de 1860 sur le commerce francobritannique", Histoire, Economie \& Société, 7 (3), pp. 279-298.

Coutain, B., 2009. "The unconditional most-favored-nation clause and the maintenance of the liberal trade regime in the postwar 1870s." International Organization, 63(1), pp.139175. 
Demier F., 2009. "Le protectionnisme français et les échanges internationaux dans la première étape de l'industrialisation," in B. Blancheton \& H. Bonin (eds.) La croissance en économie ouverte (XVIIIe-XXIe siècles), Peter Lang: Bruxelles, pp. 145-158.

Deiss F., 2018. La politique commerciale sous le Second Empire, Thèse pour le Doctorat en droit, Université de Bordeaux.

Dormois J-P., 2009. La défense du travail national? L'incidence du protectionnisme sur l'industrie en Europe (1870-1913). PUPS: Paris.

Dornbusch, R., Fischer, S. and Samuelson, P.A., 1977. "Comparative advantage, trade, and payments in a Ricardian model with a continuum of goods." The American Economic Review, 67(5), pp.823-839.

Dunham A.L., 1930. The Anglo-French Treaty of Commerce of 1860 and the Progress of the Industrial Revolution in France. Ann Arbor: University of Michigan Press.

Eaton, J. and Kortum, S., 2001. "Technology, trade, and growth: A unified framework." European Economic Review, 45(4-6), pp. 742-755.

Fan H., Li Y., Yeaple S., 2014. Trade Liberalization, Quality and Export Prices, NBER Working Paper Series, $n^{\circ} 20323$.

Federico G., 2009. "Food and globalization: consumption, markets and politics in the modern world," Economic History Review, 62(2), pp. 520-520.

Federico G., Vasta M., 2010. "Was industrialization an escape from the commodity lottery? Evidence from Italy, 1861-1939," Explorations in Economic History, 47(2), pp. 228-243.

Federico, G., Wolf, N., 2011. Comparative Advantages in Italy: a Long-run perspective, Quaderni di Storia Economica, n ${ }^{\circ}$ Banca d'Italia.

Feenstra, R C., Sasahara, A., 2017. "The 'China Shock', Exports and U.S. Employment: A Global Input-Output Analysis", NBER Working Paper No. 24022.

Gourevitch, P.A. 1977. "International Trade, Domestic Coalitions, and Liberty: Comparative Responses to the Crisis of 1873-1896" Journal of Interdisciplinary History, 8 (2), pp. 281-313.

Greenaway, D., and Milner, C., 1986. The Economics of Intra-Industry Trade, Basil Blackwell, Oxford. 
Greenaway, D., Hine, R.C., Milner, C., Elliott, R. 1994. "Adjustment and the measurement of marginal intra-industry trade." Review of World Economics, 130(2) pp. $418-427$.

Hamilton, C., and Kniest, P. 1991. "Trade liberalisation, structural adjustment and intraindustry trade: a note." Weltwirtschaftliches Archiv, 127(2) pp. 356-367.

Henriksen, I., Lampe, M. and Sharp, P., 2012. "The strange birth of liberal Denmark: Danish trade protection and the growth of the dairy industry since the mid-nineteenth century." The Economic History Review, 65(2), pp.770-788.

Huberman, M., 2008. "Ticket to trade: Belgian labour and globalization before 1914." The Economic History Review, 61(2), pp.326-359.

Irwin D., 1993. "Free Trade and Protection in the Nineteenth-Century Britain and France Revisited. A comment on Nye," Journal of Economic History, 53, pages 153-58.

Jacks, D.S., Meissner, C.M. and Novy, D. 2010. "Trade costs in the first wave of globalization." Explorations in Economic History, 47(2), pp. 127-141.

Jouannet G. 1983. "L'affirmation progressive des rapports homonymiques entre un produit et une ville: cognac et la cognac" Annales du Groupe de recherches et d'études historiques de la Charente Saintongeaise, n5, pp.13-39.

Lack, H. R. 1861. The French Treaty and Tariff of 1860. New York: Cassell, Petter and Galpin.

Lampe, M., 2009. "Effects of Bilateralism and the MFN Clause on International Trade: Evidence for the Cobden-Chevalier Network, 1860-1875." The Journal of Economic History, 69(4), pp.1012-1040.

Larique B., 2006. L'économie du tourisme en France des années 1890 à la Seconde Guerre mondiale: organisation et développement d'un secteur socio-économique. Thèse pour le doctorat en histoire, Université Bordeaux 3.

Lazer, D. 1999. "The Free Trade Epidemic of the 1860s and other Outbreaks of Economic Discrimination" World Politics, 51(4), pp. 447-483.

Levy-Leboyer, M. and Bourguignon, F. 1990. The French Economy in the Nineteenth Century: An Essay in Econometric Analysis, Cambridge University Press, Edition de la Maison des Sciences de l'Homme. 
Levy-Leboyer, M. and Bourguignon, F. 1985. p.46, Ch. 2 L'économie française au XIXè siècle. Analyse macroéconomique, Paris, Economica.

Martin, J., and Mejean I. 2014. "Low-wage country competition and the quality content of high content of high-wage country exports," Journal of International Economics, 93, pp.140-152.

O'Rourke, K.H., 1997. "The European grain invasion, 1870-1913." The Journal of Economic History, 57(4), pp.775-801.

Pahre, R. 2008. Politics and Trade Cooperation in the Nineteenth Century: The 'Agreeable Customs' of 1815-1914, Cambridge: Cambridge University Press.

Pinilla V. and Serrano R., "The Agricultural and Food Trade in the First Globalization: Spanish Table Wine Exports 1871 to 1935 - A case study." Journal of Wine Economics, 3, 2008, pp. 132-48.

Schott P.K. 2004. "Across-product versus within-product specialization in International Trade," Quarterly Journal of Economic, 119 (2), pp. 646-677.

Senger, F., 2015. La creation de l'office national du commerce extérieur (1883-1898): maîtrise de l'information competitive internationale et stratégie française de puissance. Thèse en Histoire, Université d'Artois.

Sharp, P., 2010. "'1846 and All That': the rise and fall of British wheat protection in the nineteenth century," Agricultural History Review, 58 (1), pp. 76-94.

Tena-Junguito A., Lampe M., Fernandes F., 2012. "How Much Trade Liberalization Was There in the World Before and After Cobden-Chevalier?" The Journal of Economic History, 72(03), pp. 708-740.

Todd, O., 2008. L'identité économique de la France. Paris : Grasset.

Traité de commerce conclu entre la France et la Grande-Bretagne, Paris, Typographie F Panckouche et Cie, 1860.

Verley, P., 1997. L'échelle du monde, Gallimard: Paris. 


\section{FOR ONLINE PUBLICATION Data Appendix 1}

This appendix lists the sub-products for each of the top nine exports used in this study.

\section{SILK FABRICS}

foulards écrus, foulards imprimés, étoffes unies autres, étoffes façonnées, étoffes brochées de soie étoffes brochées d'or ou d'argent fin, étoffes brochées d'or ou d'argent faux, étoffes mêlées de fil sans mélange, étoffes mêlées de fil et d'or ou d'argent fin, étoffes mêlées de fil et d'or ou d'argent faux, étoffes mêlées d'autres matières, tapis même mêlés de fil, Couvertures, gaze de soie pure, gaze de soie pure mêlée d'or ou d'argent, gaze de soie mêlée d'or ou d'argent faux, Crêpes, crêpes unis, crêpes brodés ou façonnés, Tulle, dentelles de soie dites blondes, dentelles d'or ou d'argent fin, dentelles 'd'or ou argent faux, Bonneterie, passementerie or ou argent fin, passementerie or ou argent faux, passementerie de soie pure, passementerie de soie mêlée or ou d'argent fin, passementerie de soie mêlée d'or ou d'argent faux, passementerie de soie mêlée d'autres matières, rubans même de velours, rubans de soie pure velours, rubans de soie pure autres, rubans de soie mélangée velours, rubans de soie mélangée autres, tissus de bourre de soie étoffes pures, tissus de bourre de soie couvertures, tissus de bourre de soie bonneterie, tissus de bourre de soie tapis mêlés de fil, tissus de bourre de soie passementerie et rubans, tissus de bourre de soie étoffes mélangées, tissus de soie et de bourre de soie, rubans de bourre de soie pure ou mélangée, tissus façon cachemire

\section{WOOLEN FABRICS}

Couvertures, tapis, tapis de pied simples, tapis de pied simples, à chaine de fil de lin ou de chanvre, moquettes--autres, tapis de pied simples - autres, tapis de pied à nœuds, à chaîne de fil de lin ou de chanvre simples - autres, tapis de pied à nœuds, à chaine, autres que de fil de lin ou de chanvre a nouds (a chaines et autres), tapis de toute espèce, Tapisseries, casimirs et tissus croisés, foulés et drapés, Mérinos, Draps, draps - casimirs, burail et crépon de Zurich, toile a blutoir sans couture, chaussons de lisière, étoffes diverses (serge, cacot, panne), châles brochés et façonnés, Dentelles, Bonneterie, passementerie et rubanerie, passementerie et rubanerie de pure laine, passementerie et rubanerie de pure laine blanche, passementerie et rubanerie de pure laine teinte, passementerie et rubanerie de pure laine mélangée d'autres matières, étoffes mélangées velours pour ameublement, étoffes mélangées autres, lisières de draps, étoffes mélangées, tissus d'alpaga 


\section{WINE}

vins ordinaires en futailles (combined with vins ordinaires en futailles d'ailleurs and with vins ordinaires en futailles de la Gironde), vins ordinaires en bouteilles (combined with vins ordinaires en bouteilles d'ailleurs and with vins ordinaires en bouteilles de la Gironde), vins de liqueur en futailles, vins de liqueur en bouteilles

\section{COTTON FABRICS}

toiles, percales et calicots écrus et blancs, toiles, percales et calicots teints, toiles, percales et calicots imprimés, toiles cirées et goudronnées, toiles cirées et goudronnées pour emballage, toiles cirées et goudronnées pour ameublement, tentures et autres usages, linge de table en pièces, châles et mouchoirs, Mousseline, mousselines écrues ou blanches unies, mousselines écrues ou blanches--brodées ou brochées, mousselines imprimées, draps et velours, velours façon soie. Velvets, velours autres, Cords, moleskins, etc., étoffes croisées, basins, piqués et autres, étoffes dites printanières, Couvertures, broderies à la main, dentelles fabriquées à la main et aux fuseaux, tulle avec application d'ouvrages en dentelle de fil, tulle, autres, gaze, Bonneterie, passementerie et rubanerie, Nankin, étoffes mélangées,

guinées et autres toiles à carreau des Indes, chapeaux de coton, tissus autres, tissus d'écorce en fibres de palmier, cotonnette

\section{CLOTHING}

pièces de lingerie cousues, habillements neufs, confectionnés et autres effets à l'usage des voyageurs, habillements neufs, autres, habillements vieux

\section{SILK}

soies en cocons, soies écrues gréges, soies écrues moulinées, soies écrues douppions, soies teintes pour tapisserie, soies teintes à coudre, soies teintes toutes autres, bourre en masse écrue, bourre en masse teinte, bourre cardée - frisons-peignés soies-bourre cardée toute autre, soie-bourre peignée de toute sorte, soie-bourre filée--écrue et teinte, soies-bourre filée écrue, soies-bourre filée teinte, fils de bourette ou de déchets de soie 


\section{TOOLS AND ARTICLES IN METAL}

instruments aratoires faux, instruments aratoires faucilles, instruments aratoires autres, limes et rapes à grosses tailles, limes et rapes à polir dites fines, limes et rapes à poli (fines $>17$ ), limes et rapes à polir (fines $<17 \mathrm{~cm}$ ), scies circulaires de plus de $20 \mathrm{~cm}$ de diamètre, scies circulaires de $20 \mathrm{~cm}$ et au-dessous, scies autres que circulaires, ayant comme longueur $146 \mathrm{~cm}$ ou plus , scies autres que circulaires -- ayant comme longueur moins de $146 \mathrm{~cm}$, scies autres -- ayant de longueur plus de $146 \mathrm{~cm}$, scies autres -- ayant de longueur moins de $146 \mathrm{~cm}$ et jusqu'à $50 \mathrm{~cm}$, scies autres-- ayant de longueur de $50 \mathrm{~cm}$ et au-dessous, serrans peignes à pointes d'acier, outils de pur fer, outils de fer rechargé d'acier, outils de pur acier, outils autres de cuivre ou de laiton, ouvrages en métaux dorés ou argentés, ouvrages en fonte, ouvrages en fonte non polis, ouvrages en fonte polis, ouvrages en fonte étamés émaillés vermis, ouvrages en fonte et fer non polis, ouvrages en fonte et fer polis émaillés, ouvrages en fer, ouvrages en fer tubes de tous diamètres, ouvrages en fer ferronnerie, ouvrages en fer serrurerie, ouvrages en fer clous forgés -- vis à bois--boulons et écrous, ouvrages en fer articles de ménage et autres ouvrages non dénommés en fer ou en tôle, ouvrages en tôle et fer blanc, ouvrages en fer blanc et cuivre, ouvrages en acier, ouvrages en cuivre pur ou allié communs, ouvrages en cuivre ou allié tournés fins, ouvrages en cuivre pur ou allié dorés, ouvrages en cuivre pur ou allié argentés, ouvrages en cuivre pur ou allié autres, ouvrages en plomb, ouvrages en étain poterie commune, ouvrages en étain poterie fine, poteries et autres ouvrages en étain pur ou allié, ouvrages en étain autres, ouvrages en nickel allié au zinc et au cuivre, ouvrages en zinc, ouvrages en métaux non dénommés

\section{PREPARED SKINS AND ARTICLES OF SKIN OR LEATHER}

peaux préparées d'agneau et de chevreau, peaux préparées parchemin et vélin bruts, parchemin et vélin achevés, peaux préparées cuir de veau odorant--dit de Russie, peaux préparées au tan de chèvre, peaux préparées au tan-- simplement tannées autres que de porc-grandes, peaux préparées au tan--simplement tannées autres que de porc--petites , peaux préparées pour la ganterie, peaux préparées au tan corroyées pour tiges, peaux prépares au tan corroyées autres que pour tiges de bottes, peaux préparées à l'alun hongroyées, peaux préparées à l'alun - mégissées, peaux préparées teintes de mouton, peaux préparées teintes autres, peaux préparées autres, Gants, buvards, étuis, porte-cigares, portefeuilles et porte-monnaie, sellerie grossière, outres vides, sellerie autre que les bâts non garnis de cuir, Sellerie, Chaussures, ouvrages en peau ou en cuir autres, pelleteries ouvrées 


\section{WOOL}

laines en masse -- (combined with: laines en masse dégraissées et épurées, laines en masse en suint ou lavées, laines en masse en suint communes , laines en masses en suint fines, laines en masse lavées communes, Laines en masse lavées fines), alpaga, laines peignées, laines teintes de toute sorte, déchets de laine, déchets de bourre entière, déchets de bourre lanice et tontisse

\section{FOR ONLINE PUBLICATION Appendix 2: Hidden Trade and Smuggling}

Very probably part of exports in transit does in fact include special trade. Agents might have done this in order to reduce administrative formalities. Another common problem of old trade statistics is smuggling. Considering the nature of smuggling (easy to transport, low price elasticity, a large gap in taxation levels between countries) and the example of a publication by the British government covering data on products seized, Dormois gives the conclusion "we can presume that smuggling traffic represents probably about 5\% of total trade" (Dormois, 2009: p.134).

These data do not include trade from tourism. From the establishment of the Second Empire, and with railway development, European tourism (from UK, Germany, Russia etc.) became important in France particularly in the Atlantic and Mediterranean coasts as well as in Paris (Larique, 2006). Trade from tourism and associated purchases by foreign residents may be significant during the first globalization but likely only for some headings. Specifically these would be the "articles de Paris, garments, underwear and silk fabrics".

Another common issue in 19th century trade statistics concerns the use of official prices. After 1848 the official French data show "annualised values" using standard prices defined by the Customs Value Commission (Created in December 1848). These prices supplanted the "official values" which were based on fixed values defined in 1827 and heavily criticised up to 1847 as unrealistic.

To establish the "annualized values" during the first months of year the committee defined the standard price used to value the quantity on each heading of the general tariff nomenclature. Between 1848 and 1863 the French Tableau offers both series (annualised and official values). After 1863 "official values" were removed (as in the official British data after 1854). We use "annualized values" throughout. 
Regarding imports, according to Dormois (2009), traders might be incentivized to under value the units prices in order to reduce ad valorem taxation. By computing the "mirror flows" between Belgium and France, Dormois (2009) evaluated the gap at a maximum of roughly $3.02 \%$ (Dormois, 2009: p.133). He concludes that the possible bias is unlikely to exceed 5\%. Unit values defined by the French and Belgian commissions can be different even for a relatively homogeneous heading. These differences may reveal differences in product characteristics or demand features of each market.

\section{FOR ONLINE PUBLICATION Appendix 3 Product classification}

Product classification is a crucial issue in historical trade data. The definition of the nomenclature can influence dramatically any analysis of such data.

In the Tableau Général du Commerce, French contemporaries classified exported and imported products into three main categories: agricultural products, primary products and manufactured products.

It is possible to classify products imported and exported by using Standard Industrial Classification (rev.3). Here we can consider four broad categories: agriculture, hunting and forestry (A), fishing (B), mining and quarrying (C) and manufacturing (D), the other divisions are not relevant for international trade during the period.

Some differences can be emphasized. In the contemporary source agricultural products include manufactured and processed food products (butter, cheese, refined sugar, meat, grease...) and beverages (wines, spirits), manufactures of tobacco products. Oppositely, SIC includes these products in section D (15).

A broader definition of manufacturing products offers different vision of French trade than contemporary sources offered. The shares of manufactured products in imports and exports are higher. Net exports is higher for manufacturing, particularly between the end of the 1890s and WWI. In this period there is a large contribution food products and beverages to exports in a context of increasing protection of the agricultural sector.

Nevertheless, the trends are roughly the same: between 1860 and the start of the 1880s the net export ratio manufactured products decreased quickly. This ratio was stable during the rest of Belle Epoque. The net export ratio for agricultural products is always in large deficit. 
Some good arguments justify the inclusion of processed food products into the manufactured sector: use of capital, the degree of transformation and so forth. For an economy with a diversified exports ISIC or contemporary nomenclatures can give roughly similar results, but for economies with highly concentrated exports, anomalous results can appear. In the nineteenth century, large wine exporters such as Spain and Algeria can appear as "industrialized" areas. For Spain in the 1880s wine's share in total exports was more than $30 \%$ with a peak of $40 \%$ in the mid-1880s (Pinilla \& Serrano, ${ }^{* *}$ ). Before WWI in Algeria the share of wine in total exports is greater than $40 \%$ (Meynié, 1981).

The following tables show how we classified each of the 104 products for purposes of our analysis into, exotic/tropical, primary/agricultural, semi-manufactured and manufactured. Semi-manufactured goods retain some similarities to commodities in that they are relatively homogenous. On the other hand, they are also processed using significant amounts of capital (e.g., mining and refining). The tropical/exotic goods are by and large those products not produced in metropolitan France. Different from contemporary classifications we include processed food and beverages in the manufactured rather than the agricultural sector. 
Appendix Table 3.1 Classification of 104 Products

\begin{tabular}{|c|c|c|c|}
\hline SIC code & French Name & English Name & Type \\
\hline 0.01 & 1 Arachides et noix de touloucouna & ground nuts & Tropical/exotic \\
\hline 0.02 & 2 Bois Exotiques & Tropical wood & Tropical/exotic \\
\hline 0.0113 & 3 Cacao & Cocoa & Tropical/exotic \\
\hline 0.0113 & 3 Café & Coffee & Tropical/exotic \\
\hline 0.01 & 1 Cochenille & cochineal & Tropical/exotic \\
\hline 0.02 & 2 Ecorce de quinquina & Cinchona bark & Tropical/exotic \\
\hline 0.013 & 3 Girofle & cloves & Tropical/exotic \\
\hline 0.02 & 2 Gommes exotiques & tropical rubber & Tropical/exotic \\
\hline & 4 Indigo & indigo & Tropical/exotic \\
\hline 0.01 & 1 Poivre et piment & peppers & Tropical/exotic \\
\hline 15.1 & 1 Thé & tea & Tropical/exotic \\
\hline 0.0121 & 1 Bestiaux & Animals & Primary/Ag. \\
\hline 0.02 & 2 Bois communs & Wood & Primary/Ag. \\
\hline 0.0111 & 1 Céréales & Grains & Primary/Ag. \\
\hline 17.1 & 1 Chardons cardières & cardoon thistles & Primary/Ag. \\
\hline 0.0121 & 1 Chevaux, mules et mulets & horses, donkeys, mules & Primary/Ag. \\
\hline 13.2 & 2 Étain & $\operatorname{tin}$ & Primary/Ag. \\
\hline & 4 Extraits de bois de teinture & extracts of dyeing wood & Primary/Ag. \\
\hline 0.0111 & 1 Fruits de table & fruit & Primary/Ag. \\
\hline & 4 Garance & dye: madder & Primary/Ag. \\
\hline 0.0113 & 3 Graines et fruits à ensemencer & seeds and fruits for planting & Primary/Ag. \\
\hline 0.0111 & 1 Graines et fruits oléaginaux & oil seeds and oleaginous fruits & Primary/Ag. \\
\hline 15.1 & 1 Graisse de poisson & fish fat & Primary/Ag. \\
\hline 15.1 & 1 Graisses de toute sorte & fats and grease & Primary/Ag. \\
\hline 0.01 & 1 Houblon & hops & Primary/Ag. \\
\hline 10.1 & 1 Houille crue, carbonisée et agglomérée & coal: Raw, carbonized and agg & ( Primary/Ag. \\
\hline 0.01 & 1 Jute en brins ou teillé & raw jute & Primary/Ag. \\
\hline 0.011 & 1 Lin et Chanvre & linen and hemp & Primary/Ag. \\
\hline 13.1 & 1 Minerai de fer & iron & Primary/Ag. \\
\hline 0.01 & 1 Eufs de vers à soie & silkworm eggs & Primary/Ag. \\
\hline 0.012 & 2 Oeufs & eggs & Primary/Ag. \\
\hline 0.01 & 1 Peaux et pelleteries brutes & leather and skins & Primary/Ag. \\
\hline 13.1 & 1 Plomb & lead & Primary/Ag. \\
\hline 0.01 & 1 Plumes de parure & ornamental feathers & Primary/Ag. \\
\hline 0.01 & 1 Poils propres à la filature ou a la chap & hairs for spinning, bristles & Primary/Ag. \\
\hline 0.05 & 5 Poissons frais, secs, salés... & fish & Primary/Ag. \\
\hline 0.01 & 1 Pommes de terre, légumes secs et leurs & s potatoes, legumes & Primary/Ag. \\
\hline 14.21 & 1 Potasse & potassium & Primary/Ag. \\
\hline 0.01 & $1 \mathrm{Riz}$ & rice & Primary/Ag. \\
\hline 0.05 & 5 Rogues de morue et maquereau & cod and mackerel roe & Primary/Ag. \\
\hline 0.01 & 1 Safran & saffron & Primary/Ag. \\
\hline 14.2 & 2 Sel de marais ou de saline & salt & Primary/Ag. \\
\hline 17.1 & 1 Soies & silk & Primary/Ag. \\
\hline & 4 Soufre & sulphur & Primary/Ag. \\
\hline
\end{tabular}




\begin{tabular}{|c|c|c|}
\hline French Name & English Name & Type \\
\hline 0.01 Sucres bruts & raw sugar & Primary/Ag. \\
\hline 0.01 Tabac en feuilles ou en côtes & tobacco, raw & Primary/Ag. \\
\hline 15.1 Viandes fraiches, salées... & meat & Primary/Ag. \\
\hline 13.1 Zinc & zinc & Primary/Ag. \\
\hline 24 Acide stearique, cire, bougies & Stearic acid, wax, candles & Semi-manufactured \\
\hline 36.91 Cendres et regrets d'orfevres & Cendres et regrets d'orfevres & Semi-manufactured \\
\hline 13.2 Cuivre & copper & Semi-manufactured \\
\hline 14.21 Guano et autres engrais (y compris les engrais & fertilizers (natural and synthetic) & Semi-manufactured \\
\hline 0.013 Laines en masse, peignées, teintes et déchets & raw wool, dyed wool & Semi-manufactured \\
\hline 20.2 Natte ou tresses de paille, d'écorce ou de spart & t mats, braided straw & Semi-manufactured \\
\hline 33.3 Or battu tiré laminé ou filé & gold, laminated & Semi-manufactured \\
\hline 19 Peaux préparées (et peaux tannées) & prepared hides and skins & Semi-manufactured \\
\hline 15.3 Tourteaux de graines grasses... & oil seed cake & Semi-manufactured \\
\hline 29.27 Armes poudres et munitions & Weapons, gunpowder, ammunition & Manufactured \\
\hline 24 Chandelles & candles & Manufactured \\
\hline 19 Chapeaux & hats & Manufactured \\
\hline 17.1 Coton en laine & woolen cotton fibers & Manufactured \\
\hline 24 Couleurs crayons encres & ink & Manufactured \\
\hline 28.93 Coutelerie & knives & Manufactured \\
\hline 17.1 Drilles & rags & Manufactured \\
\hline 15.51 Eaux de vie, esprits et liqueurs & Eaux de vie, spirits, licors & Manufactured \\
\hline 17.11 Fils de coton et de laine & Cotton/wool thread & Manufactured \\
\hline 17.11 Fils de lin, de chanvre & linen thread & Manufactured \\
\hline 17.11 Fils de poil de chevre & goat hair thread & Manufactured \\
\hline 13.1 Fonte, fer et acier & cast iron and steel & Manufactured \\
\hline 15.2 Fromages et beurres & butter and cheese & Manufactured \\
\hline 24 Garancine & dye: garancine & Manufactured \\
\hline 33.3 Horlogerie & watches and clocks & Manufactured \\
\hline 15.1 Huile d'olive & olive oil & Manufactured \\
\hline 15.1 Huiles de graines grasses et de fruits oléagineu: & vegetable oils, other & Manufactured \\
\hline 11.1 Huiles et essences de pétrole et de schiste & petroleum: oil and gas & Manufactured \\
\hline 11.1 Huiles volatiles et essences & oils (non-petroleum) & Manufactured \\
\hline 29 Instruments aratoires & farm implements & Manufactured \\
\hline 33 Instruments de musique & musical instruments & Manufactured \\
\hline 18.1 Lingerie et Vêtements & Clothing & Manufactured \\
\hline 29 Machines et mécaniques & machines & Manufactured \\
\hline 20 Matériaux & industrial materials & Manufactured \\
\hline 24.23 Médicaments composés & medicine, drugs & Manufactured \\
\hline 19 Modes et fleurs articielles & artificial flowers & Manufactured \\
\hline 33.3 Orfevrerie et bijouterie & jewlery & Manufactured \\
\hline 28 Outils et ouvrages en métaux & tools & Manufactured \\
\hline 19 Ouvrages en peau ou en cuir & leather products & Manufactured \\
\hline 21 Papiers et ses applications & paper & Manufactured \\
\hline
\end{tabular}




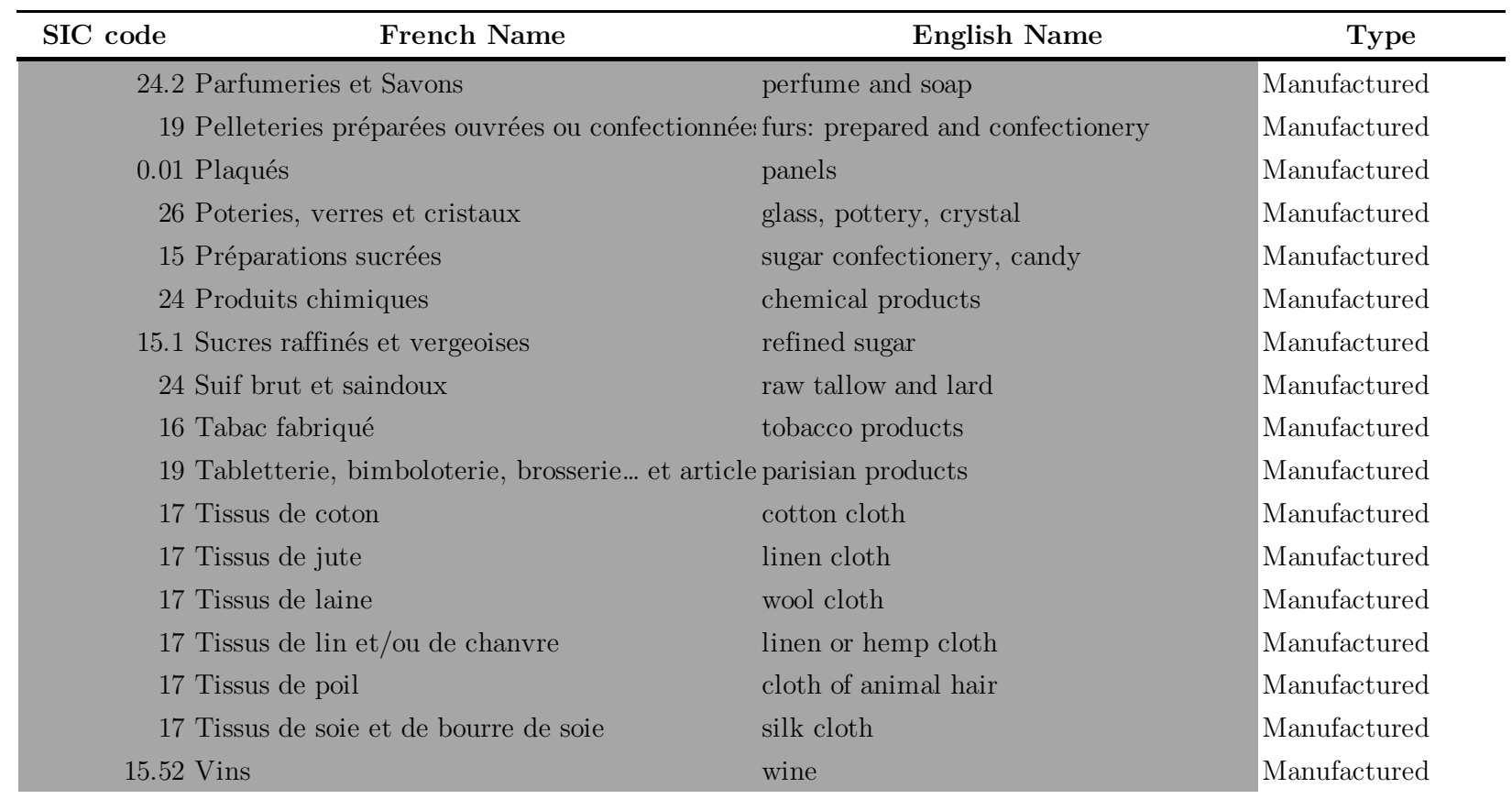


Figure 1 Evolution of the Ratio of Total Trade (Exports + Imports) to GDP and the Ratio of the Trade Balance to GDP, 1848-1888

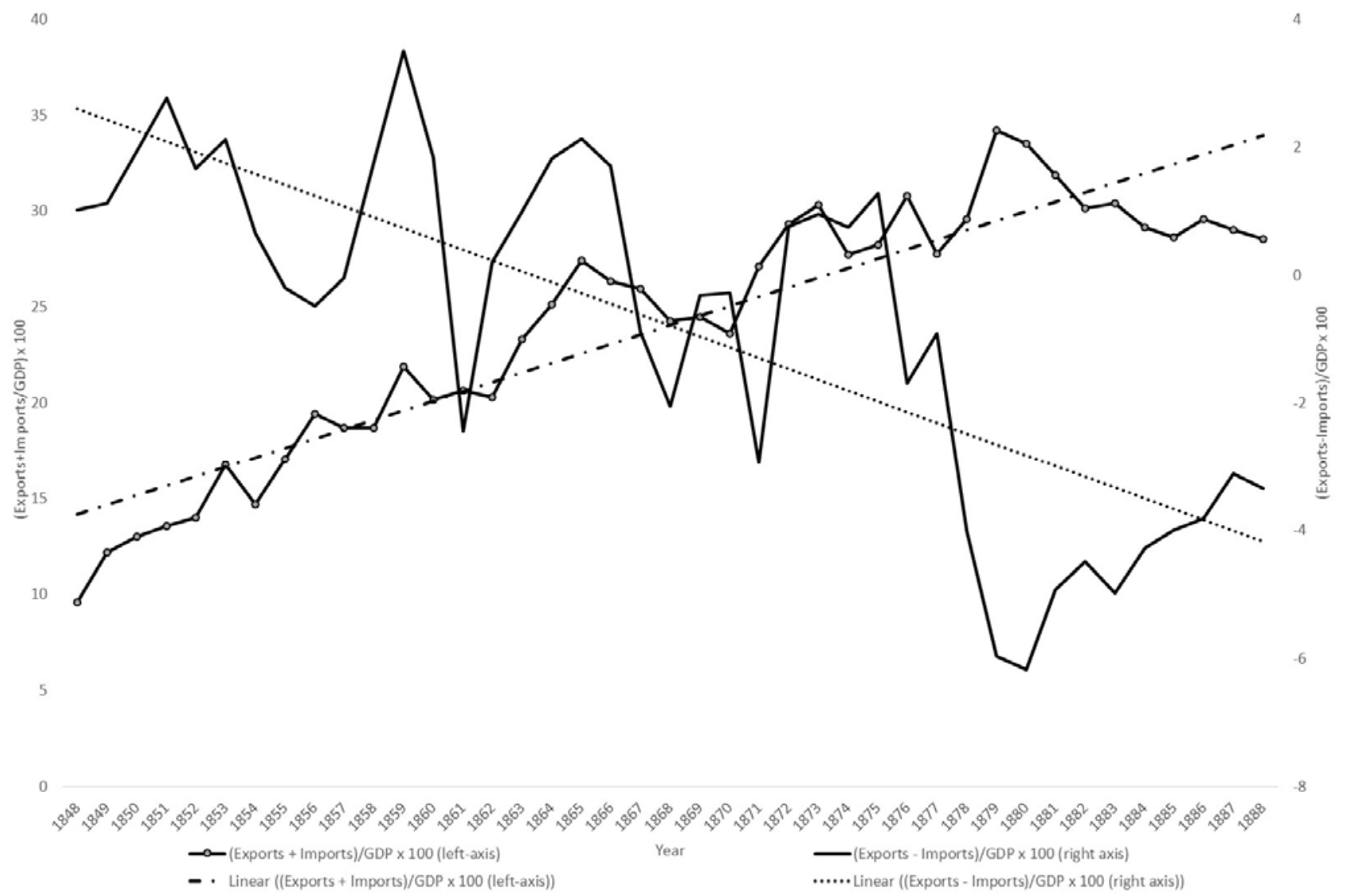

Notes: Trade data are from the Tableau. GDP data is from the Maddison project. Linear time trends are super-imposed. 
Figure 2 Average Tariff Rates for Six Final Manufactured Products, Three Intermediates, and Two Raw Materials, 1848-51 to 1869-72

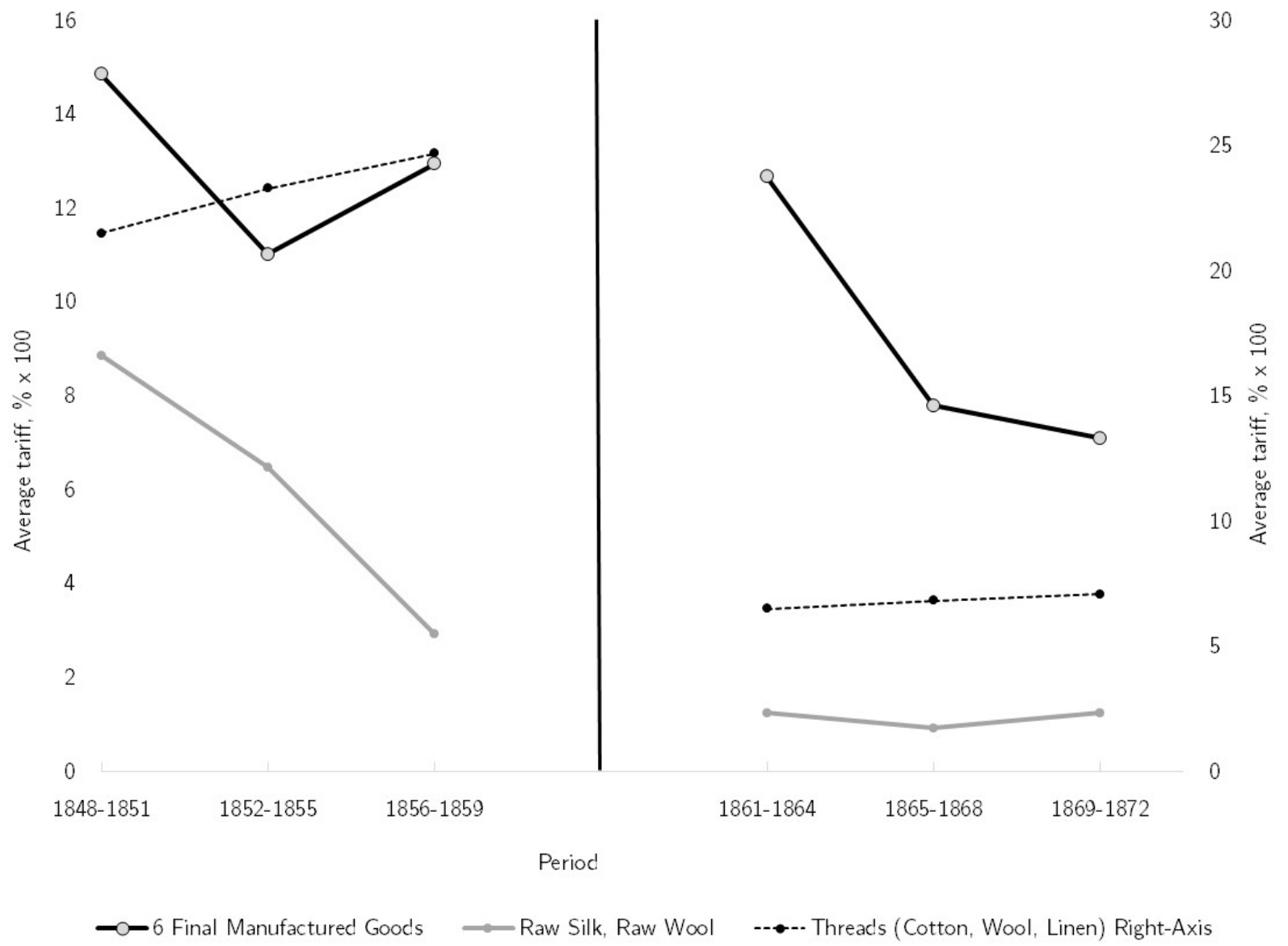

Notes: Figure shows the average tariff for three categories of products: 1) six broad product ranges of manufactured goods (clothing, leather, tools, wool cloth, cotton cloth and silk cloth), 2) raw silk and raw wool, and 3) threads (cotton, wool, linen). Tariffs are the weighted average tariffs found by dividing the total customs duties for all sub-products in the product groups by the total value of imports in the product group. Tariffs are calculated with annual data and then averaged within each three year period. 
Figure 3 Grubel-Lloyd and Aquino Indexes, 1848-1877

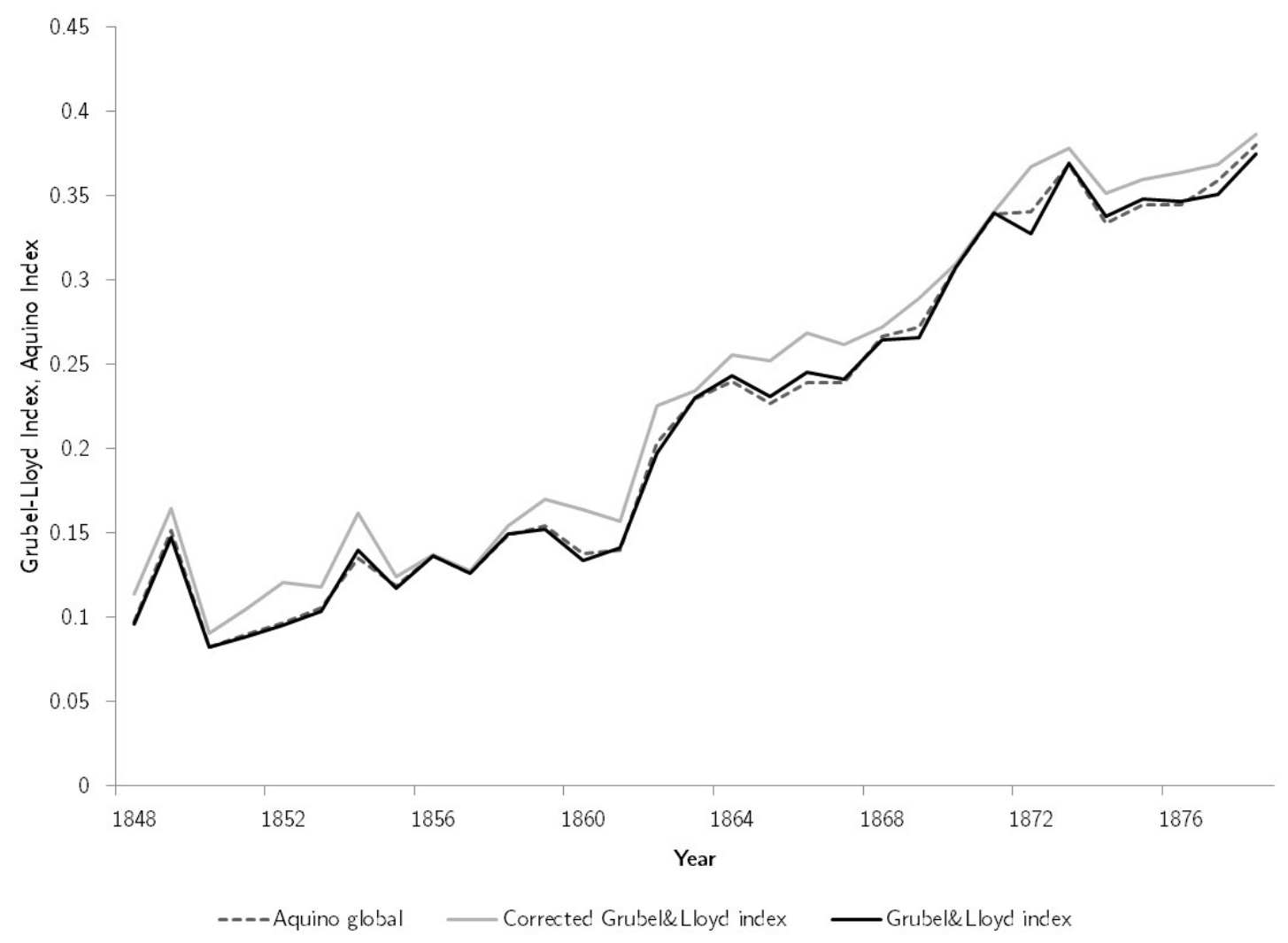

Notes: Figure shows the Grubel Lloyd, Corrected Grubel-Lloyd and Aquino indexes of intra-industry trade for 104 broad products. 
Figure 4 Net Exports for 6 Products, 1848-51 to 1869-72

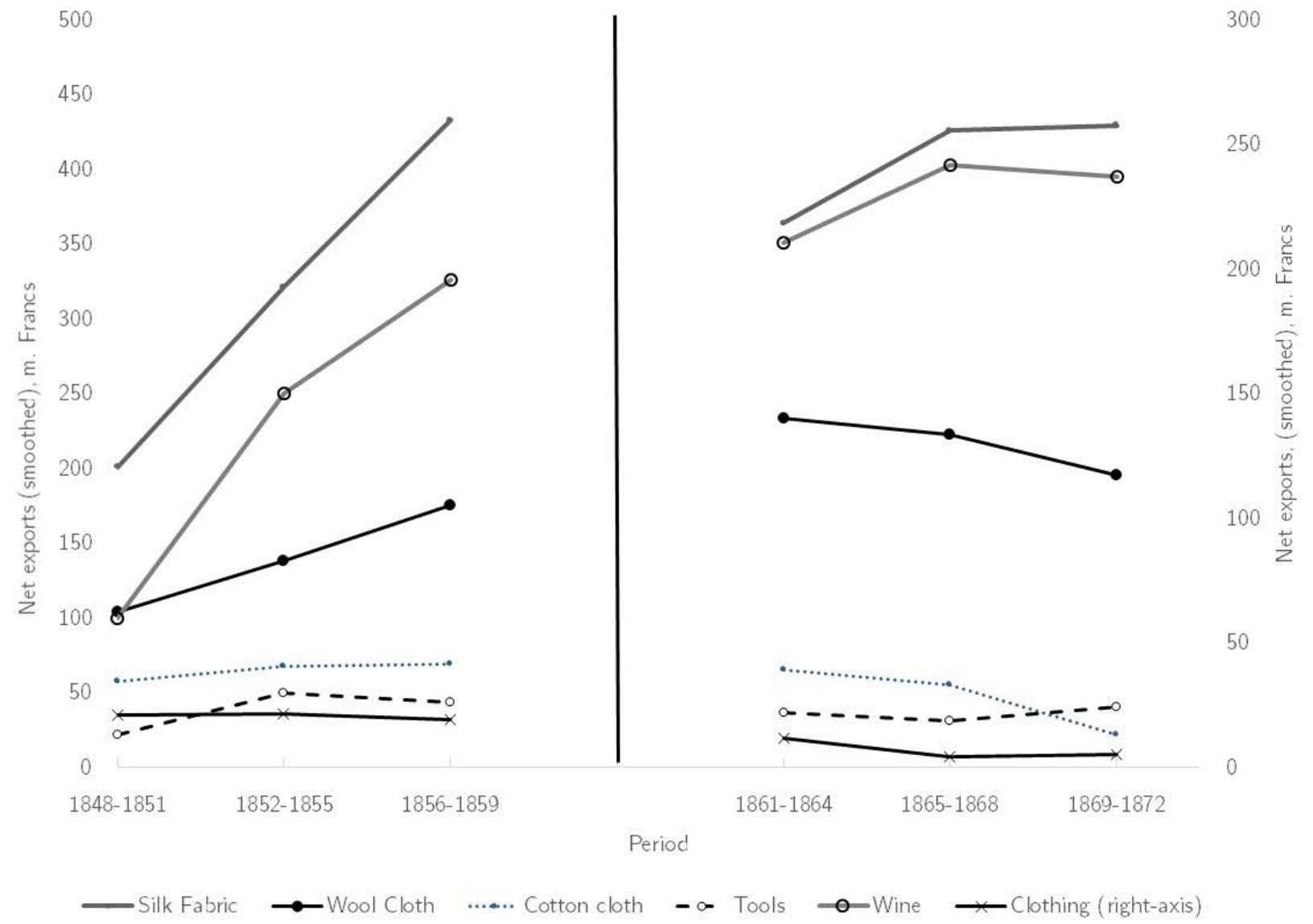

Notes: Figure shows the net exports of five of the six manufactured goods. Values are in millions of current French Francs and averaged within three year periods. Vertical line is in the last period before the Cobden Chevalier treaty of 1860. Source for data is the Tableau (see text). 
Figure 5 Estimated Evolution of Intra-Industry Trade for Top Nine Broad Product Categories, 1848-51 to 1873-76
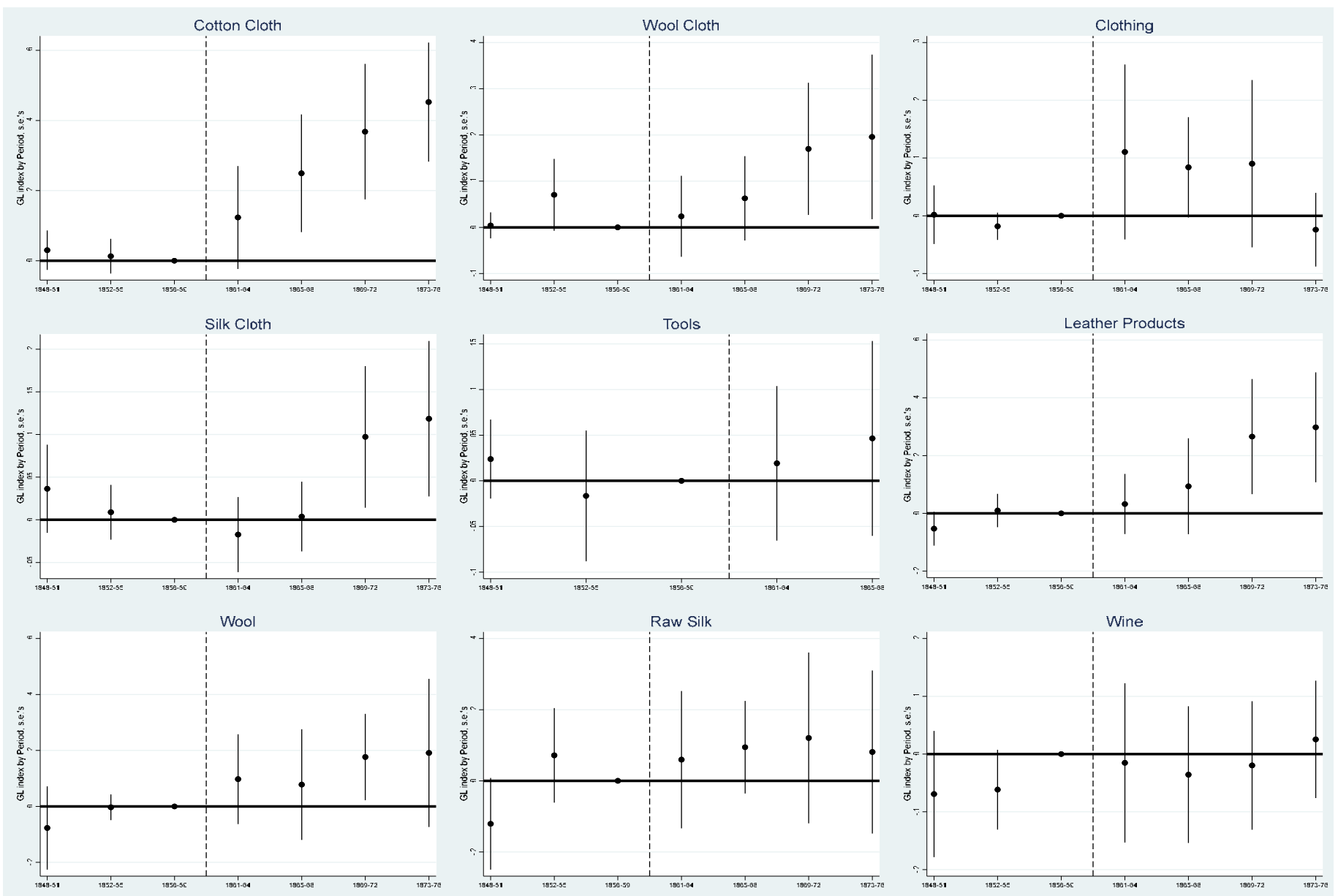

Notes: Figures show OLS estimates of the period averages for the Grubel Lloyd Index (dots) on the y-axis within each broad product class and \pm 1.96 times the clustered standard errors (bars). These averages are estimated in a panel fixed effects model with broad product class fixed effects. These data are for the sub-products within the top nine French exports and averages are relative to the 1856-59 period. There are 7 four-year periods (1848$51, \ldots, 1873-76)$ except for tools after 1868 for which data are un-available. The dashed vertical lines divide the periods before and after signing the Cobden Chevalier treaty. 
Figure 6 Event study: Impact on Grubel-Lloyd Index of MFN Clauses: Bilateral Product-Level Trade.
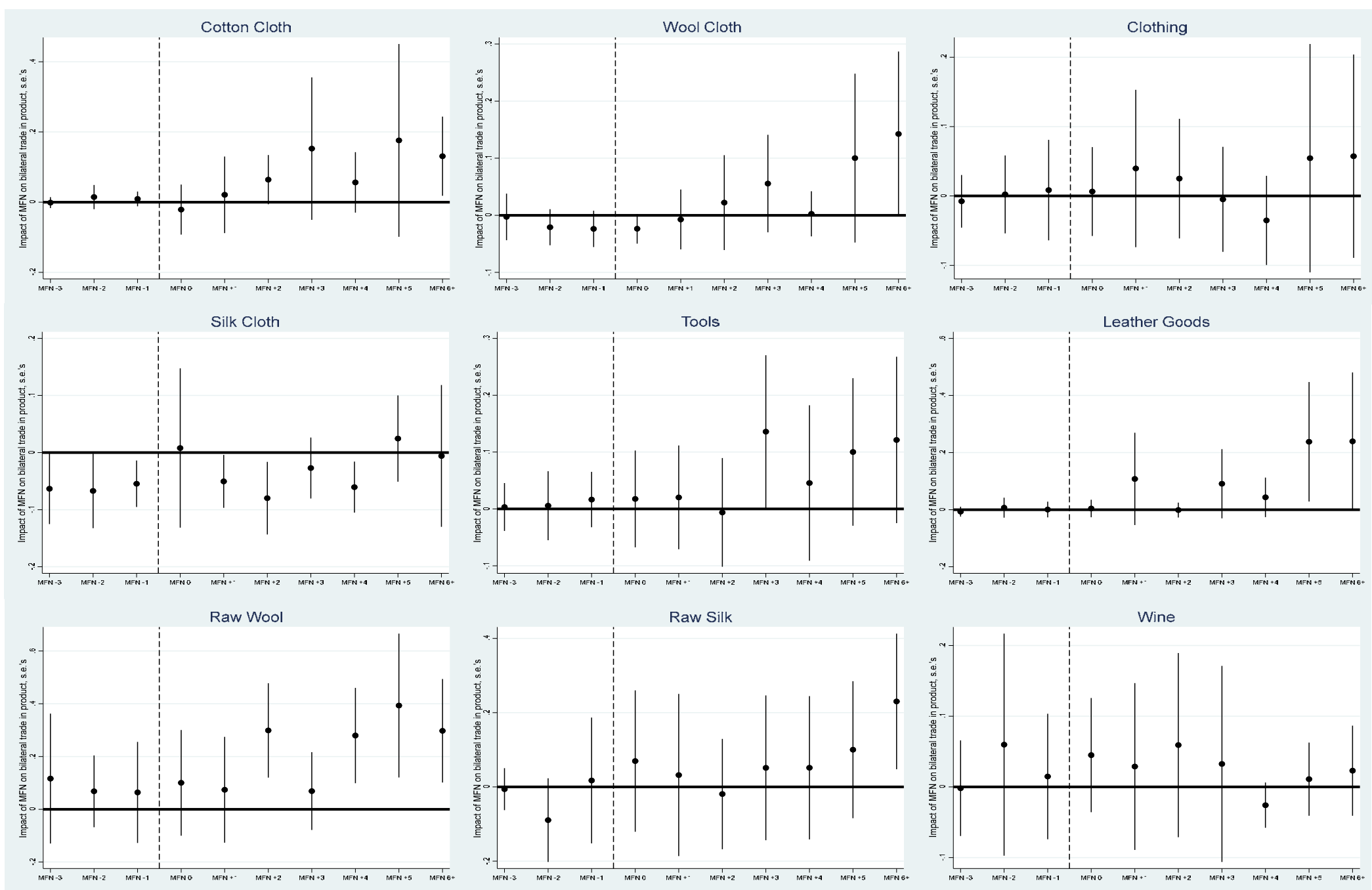

Notes: Figures show the point estimates (dots) and \pm 1.96 times the clustered standard errors (bars) for the MFN indicator in panel regressions of the bilateral $G L$ index (i.e., $G L$ is measured for a product, country, and year triplet) on time indicators and country fixed effects. The y-axis therefore measures the conditional mean of the bilateral, product level $G L$ index before and after an MFN treaty is signed. For the x-axis, the MFN indicator has 3 leads, a contemporaneous value, 5 lags and a final indicator for an active MFN treaty 6 years and beyond. Data are for 74 French trade partners between 1850 and 1870.The vertical dashed line marks the time the MFN is signed in event, not calendar time. 
Table 1 Decomposition of Growth in Gross Trade (percent x 100), 1848-51 to 1869-72

\begin{tabular}{llllll}
\hline Top 9 Exports & $1852-55$ & $1856-59$ & $1861-64$ & $1865-68$ & $1869-72$ \\
\hline MIIT & 9.65 & 9.89 & 28.62 & 32.52 & 42.67 \\
IPS & 90.35 & 90.11 & 71.38 & 67.31 & 55.32 \\
SS & -- & --- & -- & 0.17 & 2 \\
Total & 100 & 100 & 100 & 100 & 100 \\
& & & & & \\
104 Broad Products & & & & & \\
\hline MIIT & 9.96 & 12.59 & 24.43 & 30.01 & 38.75 \\
IPS & 74.33 & 79.01 & 63.15 & 60.30 & 49.32 \\
SS & 15.71 & 8.41 & 12.42 & 9.69 & 11.93 \\
Total & 100 & 100 & 100 & 100 & 100 \\
& & & & & \\
104 Products & $1861-64$ & $1865-68$ & $1869-72$ & & \\
Base Period 1856-59 & & & & & \\
\hline MIIT & 32.53 & 37.70 & 48.82 & & \\
IPS & 46.08 & 49.47 & 35.35 & & \\
SS & 21.39 & 12.83 & 15.83 & & \\
Total & 100 & 100 & 100 & & \\
\hline
\end{tabular}

Notes: Table presents the values of the growth in trade accounted for by MIIT (intra-industry trade), IPS (increase in previous specialization) and $S S$ (shifts in specialization) in percentage terms (x 100). Underlying trade data for 104 broad products and the top 9 exports, and are averaged within three year periods. The MIIT, IPS and $S S$ are weighted averages across all products with weights equal to a product's share in the sum of the absolute change of total exports and the absolute change of total imports $\left(\left|\Delta X_{t}\right|+\left|\Delta M_{t}\right|\right)$ in the base period. The base period is 1848-1851 except in the final 4 rows where it is 1856-59. 
Table 2 Determinants of Marginal Intra-Industry Trade, Increase in Previous Specialization and Specialization Shifts, 1856-59 to 1861-1864.

\begin{tabular}{|c|c|c|c|c|c|}
\hline Control & $\begin{array}{c}M I I T \\
(1) \\
\end{array}$ & $\begin{array}{c}\boldsymbol{I P S} \boldsymbol{S} \boldsymbol{S} \boldsymbol{S} \\
(2) \\
\end{array}$ & Control & $\begin{array}{c}\text { MIIT } \\
(3) \\
\end{array}$ & $\begin{array}{c}I P S-S S \\
(4) \\
\end{array}$ \\
\hline $\begin{array}{l}\text { Manufactured x } \\
1861-64\end{array}$ & $\begin{array}{c}0.08 \\
{[0.06]}\end{array}$ & $\begin{array}{c}0.11 \\
{[0.18]}\end{array}$ & $\begin{array}{l}\text { Top nine exports } \mathrm{x} \\
1861-64\end{array}$ & $\begin{array}{c}0.23^{* *} \\
{[0.09]}\end{array}$ & $\begin{array}{l}-0.00 \\
{[0.24]}\end{array}$ \\
\hline $\begin{array}{l}\text { Manufactured x } \\
1865-68\end{array}$ & $\begin{array}{l}0.12^{*} \\
{[0.06]}\end{array}$ & $\begin{array}{l}0.38^{* *} \\
{[0.17]}\end{array}$ & $\begin{array}{l}\text { Top nine exports } \mathrm{x} \\
1865-68\end{array}$ & $\begin{array}{l}0.18^{*} \\
{[0.09]}\end{array}$ & $\begin{array}{c}0.30 \\
{[0.24]}\end{array}$ \\
\hline $\begin{array}{l}\text { Manufactured x } \\
1869-72\end{array}$ & $\begin{array}{l}0.12^{*} \\
{[0.07]}\end{array}$ & $\begin{array}{c}0.33^{* *} \\
{[0.16]}\end{array}$ & $\begin{array}{l}\text { Top nine exports } \mathrm{x} \\
1869-72\end{array}$ & $\begin{array}{c}0.44^{* * *} \\
{[0.10]}\end{array}$ & $\begin{array}{c}0.27 \\
{[0.17]}\end{array}$ \\
\hline $\begin{array}{l}\text { Observations } \\
\mathrm{R}^{2}\end{array}$ & $\begin{array}{l}296 \\
0.04\end{array}$ & $\begin{array}{l}296 \\
0.03\end{array}$ & & $\begin{array}{l}296 \\
0.10\end{array}$ & $\begin{array}{l}296 \\
0.01\end{array}$ \\
\hline
\end{tabular}

Notes: Dependent variable is $M I I T$ or the difference between IPS and $S S$ taken for one of three postliberalization periods relative 1856-59. See text for formulae. Data are smoothed within each three year period. Data comprise all main products (104) in official trade data. Estimation is by OLS. A constant and period indicators are included but not reported. Robust standard errors in brackets are clustered at the product level. 
Table 3 Evolution of the Grubel-Lloyd and Intra-Industry Trade, Three post-Cobden Chevalier Periods Compared to 1856-59, Broad Products

\begin{tabular}{|c|c|c|c|c|c|c|}
\hline Manufactured & $\begin{array}{l}G \boldsymbol{L} \\
(1) \\
\end{array}$ & $\begin{array}{r}\boldsymbol{I I T} \\
(2) \\
\end{array}$ & $\begin{array}{c}\ln (\boldsymbol{I I T}) \\
(3) \\
\end{array}$ & $\begin{array}{l}G \boldsymbol{L} \\
(4) \\
\end{array}$ & $\begin{array}{l}\boldsymbol{I I T} \\
(5) \\
\end{array}$ & $\begin{array}{c}\ln (\boldsymbol{I I T}) \\
(6) \\
\end{array}$ \\
\hline Tariff & $\begin{array}{c}-0.70^{*} \\
{[0.36]}\end{array}$ & $\begin{array}{c}-68.67^{* *} \\
{[32.14]}\end{array}$ & $\begin{array}{l}-1.93 \\
{[1.36]}\end{array}$ & & & \\
\hline $\begin{array}{l}\text { Prohibition pre- } 1860 \\
\text { x post } 1860\end{array}$ & & & & $\begin{array}{c}0.18^{* *} \\
{[0.07]}\end{array}$ & $\begin{array}{r}8.00 \\
{[9.24]}\end{array}$ & $\begin{array}{c}0.41 \\
{[0.29]}\end{array}$ \\
\hline Observations & 96 & 96 & 96 & 272 & 272 & 272 \\
\hline Number of products & 24 & 24 & 24 & 68 & 68 & 68 \\
\hline $\mathrm{R}^{2}$ & 0.26 & 0.35 & 0.20 & 0.17 & 0.21 & 0.05 \\
\hline
\end{tabular}

Notes: Dependent variable in columns 1 and 4 is the Grubel Lloyd Index. In columns 2 and 5 it is IIT - a measure of intra-industry trade. Columns 3 and 6 use the ln (IIT) measure. See text for formulae. Data are smoothed within four year periods with simple averaging. Data comprise all main products in official trade data with balanced data for all variables available. Estimation is by OLS. Robust standard errors are in brackets are clustered at the product level. 
Table 4 Marginal Intra-Industry Trade and Specialization Shifts Sub-Products for Top 9 Exports, 1856-59 and Three post-Cobden Chevalier Periods

\begin{tabular}{|c|c|c|c|c|c|c|c|c|c|}
\hline \multirow[b]{2}{*}{ Category } & \multicolumn{4}{|c|}{ MIIT } & \multirow[b]{2}{*}{ Category } & \multicolumn{4}{|c|}{ IPS - SS } \\
\hline & (1) & (2) & (3) & $(4)$ & & $(5)$ & $(6)$ & $(7)$ & $(8)$ \\
\hline \multirow[t]{2}{*}{ Manufactured } & $-0.18^{* * *}$ & & & & Manufactured & $-0.26^{*}$ & & & \\
\hline & {$[0.06]$} & & & & & {$[0.16]$} & & & \\
\hline \multirow[t]{2}{*}{$\Delta$ tariff $t-(1856-1859)$} & & & & $0.59^{* * *}$ & $\Delta$ in tariff $t-(1856-1859)$ & & & & $1.04^{*}$ \\
\hline & & & & {$[0.19]$} & & & & & {$[0.56$} \\
\hline \multirow[t]{2}{*}{ Clothing } & & $0.10^{*}$ & 0.08 & & Clothing & & 0.10 & $0.53^{* *}$ & \\
\hline & & {$[0.06]$} & {$[0.08]$} & & & & {$[0.41]$} & {$[0.21]$} & \\
\hline \multirow[t]{2}{*}{ Wool } & & $0.27^{* *}$ & $0.28^{* * *}$ & & Wool & & -0.23 & $0.42^{* *}$ & \\
\hline & & {$[0.12]$} & {$[0.05]$} & & & & [0.33] & {$[0.17]$} & \\
\hline \multirow[t]{2}{*}{ Tools } & & $0.07^{* *}$ & 0.15 & & Tools & & $-0.41^{* * *}$ & $-0.55^{* * *}$ & \\
\hline & & {$[0.03]$} & {$[0.11]$} & & & & {$[0.12]$} & {$[0.17]$} & \\
\hline \multirow[t]{2}{*}{ Leather } & & $0.17^{* * *}$ & $0.19^{* * *}$ & & Leather & & 0.14 & 0.18 & \\
\hline & & {$[0.05]$} & {$[0.07]$} & & & & {$[0.13]$} & {$[0.17]$} & \\
\hline \multirow[t]{2}{*}{ Silk } & & $0.32^{* * *}$ & $0.51^{* * *}$ & & Silk & & 0.06 & 0.09 & \\
\hline & & {$[0.08]$} & {$[0.18]$} & & & & {$[0.15]$} & {$[0.10]$} & \\
\hline \multirow[t]{2}{*}{ Cotton cloth } & & $0.15^{* * *}$ & $0.20^{* * *}$ & & Cotton cloth & & $-0.55^{* * *}$ & $-0.67^{* * *}$ & \\
\hline & & {$[0.05]$} & {$[0.06]$} & & & & {$[0.12]$} & {$[0.12]$} & \\
\hline \multirow[t]{2}{*}{ Wool cloth } & & $0.11^{* *}$ & $0.31^{* *}$ & & Wool cloth & & 0.02 & 0.19 & \\
\hline & & {$[0.05]$} & {$[0.12]$} & & & & [0.20] & {$[0.24]$} & \\
\hline \multirow[t]{2}{*}{ Silk cloth } & & 0.02 & $0.12 * * *$ & & Silk cloth & & $-0.32 * * *$ & 0.17 & \\
\hline & & {$[0.02]$} & {$[0.04]$} & & & & {$[0.12]$} & {$[0.37]$} & \\
\hline \multirow[t]{2}{*}{ Wine } & & 0.12 & -0.04 & & Wine & & 0.18 & 0.43 & \\
\hline & & {$[0.15]$} & {$[0.04]$} & & & & {$[0.44]$} & {$[0.44]$} & \\
\hline Observations & 523 & 523 & 523 & 218 & & 507 & 507 & 507 & 211 \\
\hline $\mathrm{R}^{2}$ & 0.09 & 0.37 & 0.67 & 0.08 & & 0.02 & 0.14 & 0.32 & 0.03 \\
\hline
\end{tabular}

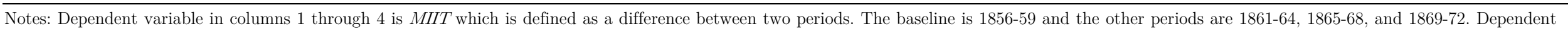

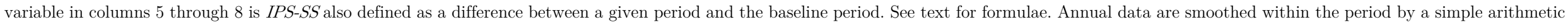

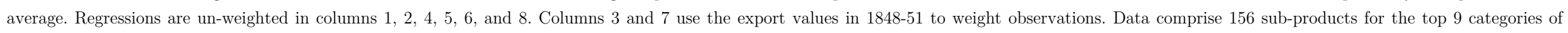
exports. Estimation is by OLS. Robust standard errors are in brackets are clustered at the broad product level. 
Table 5 Evolution of the Grubel-Lloyd and Intra-Industry Trade, 1848-51 to 1873-76, 163 sub-products from the top 9 Exports.

\begin{tabular}{|c|c|c|c|c|c|c|}
\hline & $\begin{array}{l}G \boldsymbol{L} \\
(1) \\
\end{array}$ & $\begin{array}{l}\boldsymbol{I I T} \\
(2) \\
\end{array}$ & $\begin{array}{c}\ln (\boldsymbol{I I T}) \\
(3) \\
\end{array}$ & $\begin{array}{l}G \boldsymbol{L} \\
(4) \\
\end{array}$ & $\begin{array}{c}I I T \\
(5) \\
\end{array}$ & $\begin{array}{c}\ln (\boldsymbol{I I T}) \\
(6) \\
\end{array}$ \\
\hline Tariff & $\begin{array}{c}-0.26^{* * *} \\
{[0.09]}\end{array}$ & $\begin{array}{c}5,154.44 \\
{[4,655.49]}\end{array}$ & $\begin{array}{r}-0.39^{*} \\
{[0.21]}\end{array}$ & & & \\
\hline $\begin{array}{l}\text { Prohibition pre- } 1860 \mathrm{x} \\
\text { post } 1860\end{array}$ & & & & $\begin{array}{l}0.07^{*} \\
{[0.04]}\end{array}$ & $\begin{array}{r}-4,179.41^{*} \\
{[2,311.70]}\end{array}$ & $\begin{array}{c}0.15 \\
{[0.10]}\end{array}$ \\
\hline Observations & 661 & 661 & 661 & 903 & 903 & 903 \\
\hline $\mathrm{R}^{2}$ & 0.13 & 0.08 & 0.06 & 0.15 & 0.09 & 0.08 \\
\hline
\end{tabular}

Notes: Dependent variable is given at the top of each column. Time dummies and sub-product dummies are included but not reported. See text for formulae. Data are smoothed within four year periods with simple averaging. Estimation is by OLS. Robust standard errors are in brackets are clustered at the sub-product level. 
Table 6 Evolution of Exports, Imports and Net Exports, 1848-51 to 1873-76

\begin{tabular}{|c|c|c|c|c|c|c|c|c|c|c|c|c|}
\hline & \multicolumn{6}{|c|}{104 Broad Products } & \multicolumn{6}{|c|}{189 Sub-Products from top 9 Broad Products } \\
\hline & $\begin{array}{c}\ln (\mathrm{X}) \\
(1) \\
\end{array}$ & $\begin{array}{c}\ln (\mathbf{M}) \\
(2) \\
\end{array}$ & $\begin{array}{c}\ln (\mathrm{X} / \mathrm{M}) \\
(3) \\
\end{array}$ & $\begin{array}{c}\ln (\mathrm{X}) \\
(4) \\
\end{array}$ & $\begin{array}{c}\ln (\mathrm{M}) \\
(5) \\
\end{array}$ & $\begin{array}{c}\ln (\mathrm{X} / \mathrm{M}) \\
(6) \\
\end{array}$ & $\begin{array}{c}\ln (\mathrm{X}) \\
(7) \\
\end{array}$ & $\begin{array}{c}\ln (\mathrm{M}) \\
(8) \\
\end{array}$ & $\begin{array}{c}\ln (\mathrm{X} / \mathrm{M}) \\
(9) \\
\end{array}$ & $\begin{array}{c}\ln (\mathrm{X}) \\
(10) \\
\end{array}$ & $\begin{array}{c}\ln (\mathbf{M}) \\
(11) \\
\end{array}$ & $\begin{array}{c}\ln (\mathrm{X} / \mathrm{M}) \\
(12) \\
\end{array}$ \\
\hline Tariff & $\begin{array}{l}-0.01 \\
{[0.01]}\end{array}$ & $\begin{array}{c}-0.03^{* * *} \\
{[0.01]}\end{array}$ & $\begin{array}{c}0.02 \\
{[0.01]}\end{array}$ & & & & $\begin{array}{c}-0.97^{* *} \\
{[0.47]}\end{array}$ & $\begin{array}{c}-1.58^{* *} \\
{[0.77]}\end{array}$ & $\begin{array}{c}0.61 \\
{[0.97]}\end{array}$ & & & \\
\hline $\begin{array}{l}\text { Prohibition pre- } \\
1860 \times \text { x post- } 1860\end{array}$ & & & & $\begin{array}{c}-0.26 \\
{[0.16]}\end{array}$ & $\begin{array}{c}1.35^{* * *} \\
{[0.23]}\end{array}$ & $\begin{array}{c}-1.61^{* * *} \\
{[0.28]}\end{array}$ & & & & $\begin{array}{l}-0.03 \\
{[0.30]}\end{array}$ & $\begin{array}{c}1.69^{* * *} \\
{[0.43]}\end{array}$ & $\begin{array}{c}-1.72^{* * *} \\
{[0.45]}\end{array}$ \\
\hline Observations & 190 & 190 & 190 & 624 & 624 & 624 & 661 & 661 & 661 & 1,206 & 1,206 & 1,206 \\
\hline $\mathrm{R}^{2}$ & 0.33 & 0.62 & 0.08 & 0.26 & 0.37 & 0.17 & 0.19 & 0.22 & 0.02 & 0.08 & 0.26 & 0.14 \\
\hline
\end{tabular}

Notes: Dependent variable is given at the top of each column. $\mathbf{X}$ stands for exports, $\mathbf{M}$ for imports. Time dummies and sub-product or product dummies are included but not reported. See text for formulae. Data are smoothed within four year periods with simple averaging. Estimation is by OLS. Robust standard errors are in brackets are clustered at the sub-product level. 
Table 7 Association between MFN-Treaties of Commerce and Bilateral Intra-Industry Trade, 1850-1870

$(1)$

\begin{tabular}{|c|c|c|c|c|c|c|c|}
\hline \multirow[t]{2}{*}{ MFN } & $0.07 * *$ & 0.02 & 0.02 & & & & \\
\hline & {$[0.02]$} & {$[0.01]$} & {$[0.01]$} & & & & \\
\hline \multirow[t]{2}{*}{ MFN GB } & & & & $0.06^{* *}$ & $\operatorname{MFN}(-3)$ & -0.01 & $-0.03^{* *}$ \\
\hline & & & & {$[0.02]$} & & {$[0.01]$} & {$[0.01]$} \\
\hline \multirow[t]{2}{*}{ MFN Belgium } & & & & $0.13^{* * *}$ & $\operatorname{MFN}(-2)$ & -0.00 & -0.03 \\
\hline & & & & {$[0.02]$} & & {$[0.01]$} & {$[0.02]$} \\
\hline \multirow[t]{2}{*}{ MFN Turkey } & & & & -0.01 & $\operatorname{MFN}(-1)$ & -0.00 & $-0.03^{*}$ \\
\hline & & & & {$[0.01]$} & & {$[0.02]$} & {$[0.02]$} \\
\hline \multirow[t]{2}{*}{ MFN Hanseatic } & & & & $0.18^{* * *}$ & $\operatorname{MFN}(0)$ & 0.02 & -0.02 \\
\hline & & & & {$[0.03]$} & & {$[0.02]$} & {$[0.02]$} \\
\hline \multirow[t]{2}{*}{ MFN Italy } & & & & 0.04 & $\operatorname{MFN}(+1)$ & 0.03 & -0.02 \\
\hline & & & & {$[0.03]$} & & {$[0.02]$} & {$[0.03]$} \\
\hline \multirow[t]{2}{*}{ MFN Switzerland } & & & & -0.00 & $\operatorname{MFN}(+2)$ & 0.04 & -0.01 \\
\hline & & & & {$[0.01]$} & & {$[0.03]$} & {$[0.04]$} \\
\hline \multirow[t]{2}{*}{ MFN Sweden } & & & & 0.00 & $\operatorname{MFN}(+3)$ & $0.06^{* *}$ & 0.01 \\
\hline & & & & {$[0.00]$} & & {$[0.03]$} & {$[0.02]$} \\
\hline \multirow[t]{2}{*}{ MFN Norway } & & & & $0.03^{*}$ & $\operatorname{MFN}(+4)$ & 0.04 & -0.03 \\
\hline & & & & {$[0.01]$} & & {$[0.04]$} & {$[0.03]$} \\
\hline \multirow[t]{3}{*}{ MFN Netherlands } & & & & $0.13^{* * *}$ & $\operatorname{MFN}(+5)$ & $0.12^{* *}$ & 0.05 \\
\hline & & & & {$[0.03]$} & & {$[0.05]$} & {$[0.04]$} \\
\hline & & & & & $\mathrm{MFN}$ & & \\
\hline MFN Spain & & & & $\begin{array}{l}-0.01 \\
{[0.01]}\end{array}$ & $(+6$ or more $)$ & $\begin{array}{l}0.13^{* *} \\
{[0.04]}\end{array}$ & 0.04 \\
\hline \multirow[t]{2}{*}{ MFN Portugal } & & & & -0.01 & & & \\
\hline & & & & {$[0.01]$} & & & \\
\hline Observations & 7,489 & 7,489 & 7,489 & 7,489 & & 7,489 & 7,489 \\
\hline $\mathrm{R}^{2}$ & 0.18 & 0.19 & 0.20 & 0.19 & & 0.19 & 0.20 \\
\hline Country Fixed Effects & yes & yes & yes & yes & & yes & yes \\
\hline Year Fixed Effects & yes & yes & yes & yes & & yes & yes \\
\hline Product Fixed Effects & yes & yes & yes & yes & & yes & yes \\
\hline \multicolumn{8}{|l|}{ Country Fixed Effects } \\
\hline x Trend & no & yes & yes & no & & no & yes \\
\hline \multicolumn{8}{|l|}{ Product Fixed Effects } \\
\hline $\mathrm{x}$ Trend & no & no & yes & no & & no & yes \\
\hline
\end{tabular}

Notes: Dependent variable is the Grubel-Lloyd index of intra-industry trade at the bilateral, product level. See text for formula. MFN $=1$ when a treaty of commerce and navigation is in effect. Data comprise the top 9 broad categories of exports and cover 74 trade partners. Standard errors clustered at the trade partner and product level are in brackets. 